\title{
influencias Culturales y Expresión Personal en "Los Heraldos Negros"
}

Por ANDRÉ COYNÉ

\section{INTRODUCCION}

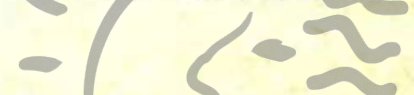

Para toda valoración posterior de la obra de madurez de Vallejo, es de sumo interés examinar previamente el libro de la juventud que. si bien debe mucho $\alpha$ la estética entonces vigente, inicia al mismo tiempo una ruptura inequívoca con la misma y logra definir un nuevo mo do de expresión. pos Completodiberado de las formas $v$ técnicas modernistas. En su agresiva originalidad Trilce será tributario del esfuerzo de liberación patente "a los largo de Los Heraldos Negros, y mucho más tarde, a pesar del transcurso del tiempo, los Poemas Humanos no desmentirán la intuición primordial del libro de 1918, sino que al contrario chondarán en ella con una conciencia agudizada por la proximidad de la muerte.

Antes de entrar a estudiar el primer libro de Vallejo, no creo que sea preciso entablar una historia detallada de la vida del poeta, cuyos rasgos más importantes, por lo demás, he tratada personalmente de establecer hace ya algunos años en una revista limeña (1). Cabe sin embargo recordar aquí brevemente aquellos pormenores biográficos $\alpha$ los cuales el escritor alude, expresa o tócitamente, en el texto de 1918 , ya que ellos, sin tener mayor importancia estética, no dejan de ser necesarios para la comprensión inmediata de los poemas.

\footnotetext{
(1) Apuntes biográficos de César Vallejo. Mar del Sur, No. 8, Nov. Dic. I949.
} 
Mayo y Aldeana por ejemplo evocan la existencia sosegada de las pequeñas ciudades serranas y especialmente de la que más recuerdos dejara a quien nació bajo su cielo, Santiago de Chuco, en los dos mo. mentos privilegiados del alba y del crepúsculo. El humo de los bohíos, el pueblo que despierta con la luz, las tareas campesinas que se inician, "zagalas" y jóvenes labradores que alternan los gestos ancestrales del trabajo con los cantos de su pena nostálgica, mientras los ancianos están ya delante de sus chozas, fumando o masticando coca; es la aurora. La aflicción del día a punto de morir, las esquilas de los rebaños que vuelven a los establos, y en el silencio que lo invade todo el agrio llorar de una quena, el triste desgarrar de una guitarra acompañando los acentos melancólicos de un yaraví : es el crepúsculo.

En Aldeana igualmente el poeta recuerda más precisamente la casa donde se desarrolló su niñez: el inmenso portón por donde podían entrar las cabalgaduras (cf. asimismo: Hojas de Ebano), el "patio silente" con su poyo de piedra, la huerta hoy desaparecida, con el muro en donde niño apoyábase, mirando muy cerca el "cementerio" (Enereida), el "blanco panteón" que ha de ser algún día el último "cautiverio" (Ausente), o tal vez elaborando sueños lejanos de misterio y de gloria (vestir hábitos sagrados, ser obispo : "una mitra de ensueño que perdí" - Comunión) (2), después de haber "chivateado" todo el día (Mayo) y contentado las" "ganas lindas" que tenía de "almorzar y beber del arroyo". Toda una vida monótona que sólo una vez al año animara $Y$ alegrara la celebración del santo patrón de la "ciudad, Santiago, el apóstol por antonomasia, el mismo que el "labriego" en su ingenua devoción confunde facilmente con el dios-sol de sus antepasados: de las fiestas anuales de su ciudad natal, con el típico ambiente de religión, bailoteo y borracheras, Vallejo nos ha dejado una evocación poética en los sonetos de Terceto Autóctono.

A través de los poemas que integran Canciones de Hogar podemos asimismo evocar a quienes rodearon de quietud y cariño la infancia secretamente adolorida del poeta: no muy lejos de la iglesia, a cuya sombra el muchachito de largas trenzas iría a oir las historias y consejas del campanero, el "buen ciego mélico", Santiago, quien murió hace muy pocos años después de ser durante más de medio siglo el confidente predilecto de todos los niños del lugar, - no muy lejos de la iglesia, - el hijo de D. Francisco de Paula Vallejo y de Dña. María

(2) cf. Francisco Izquierdo Ríos: Vallejo y su tierra - p. 22. 
de los Santos Mendoza vivía con los suyos, entre sus padres y sus hermanas mayores, uno de los cuales había de tomar en serio una noche de agosto de 1915 el juego del escondite de otrora y ocultarse para siempre en las tinieblas de la muerte, dando origen al poema que se titula $A$ mi hermano Miguel.

A su padre también, a quien alude por ejemplo en Los pasos lejanos, Vallejo dedica un poema entero de Los Heraldos Negros : Enereida. Antes del año 1900 Santiago de Chuco, elevada a provincia solamente en los últimos meses del siglo pasado, no era más que un distrito, dependencia de la provincia de Huamachuco, y D. Francisco de Paula Vallejo había sido un tiempo gobernador del distrito, lo que explica en Enereida, la alusión a "los años de la gobemación"; parece que el hijo conservara de su padre el recuerdo de un hombre ya anciano (había nacido probablemente en 1840, y le llevaba unos diez años a su esposa), austero, o mejor dicho augusto en todos los sentidos que encierra dicha palabra, grave, religioso, apacible y a la vez tierno con el menor de sus descendientes.

En cuanto a la madre, que inspiraría después de muerta muchos poemas de Trilce, la vemos aparecer en algunas composiciones de 1918, símbolo de un amor inquieto (Los pasos lejanos) que abarca hasta las cosas más humildes (Las piedras) Y protege al niño contra los "golpes" de la vida; (en Nervazón de angustia la amada será llamada a desempeñar papel idéntico: "oh, nueva madre mia".), dóndcle al despertar las "empanadas"gcon que saciar su hambre (Enereida) y luego ese "Pan nuestro de cada día" (EI pan nuestro), que tanta falta le había de hacer más tarde. En Hojas de Ebano, poema de la noche serrana, noche de "sepultura" y "funerales" fría, triste, lluviosa, podemos encontrar, a través probablemente del recuerdo de otra persona desaparecida (3), como el eco anticipado de la muerte que pronto asolaría el alma ya derrotada del poeta: "Si señor; murió en la aldea; aún la veo envueltita en su rebozo......".

En Abril de 1905, Vallejo va por primera vez a Huamachuco; desde entonces empieza a cruzar con relativa frecuencia las "rocallosas jalcas peruanas" y aquellos paisajes cuya atmósfera preñada "de

(3) ¿Será la, pequeña Maria una de sus hermanas, prcmaturamente desaparecida, y cuya sombra se mezclará mucho más tarde con las de la madre y del hermano Miguel, en la prosa de Pocmas Humanos titulada La V'iolencia de las Horas donde también aparecen otros muertos santiaguinos? 
electricidad y de hórrido presagio" evocaría en su prosa titulada Fabla Salvaje. En Los Heraldos Negros tan sólo presentimos los "Andes occidentales de la Eternidad", pero un poema como Los Arrieros nos transmite la emoción de los viajes ya más largos que en una época sensiblemente posterior el estudiante había de realizar anualmente desde Santiago de Chuco hasta Trujillo; no existía entonces la carretera que une ahora las dos ciudades distantes, unos $180 \mathrm{kms}$., y la ida, a caballo, duraba varios días, días interminables durante los cuales los viajeros desgramaban la "oración del camino" y apenas cruzaban de vez en cuando unos arrieros emponchados "saboreando el romance peruano de su coca"; la cabalgata terminaba a $20 \mathrm{kms}$. de Trujillo, a la altura de la hacienda de Menocucho, también mencionada en el poema (4), donde abandonaban los caballos para tomar el tren que iba a la capital de La Libertad. A fines de diciembre, Vallejo subía nuevamente a Santiago, para regresar hacia la costa, después de terminadas las vacaciones en el mes de marzo o abril; una vez, al poco tiempo de abandonar la ciudad andina con su hermano Néstor, el poeta, cuando iba por las alturas desoladas de la jalca, empezó a tiritar de fiebre y tuvo que regresar a la casa de sus padres; los días que ahí pasó, habrían originado el poema Encaje de Fiebre.

En los sonetos de Nostalgias Imperiales, réplica costeña del cuadro serrano de Terceto Aútóctono, tenemos el reflejo de los años de Trujillo y los paseos o diversiones del pequeño núcleo intelectual al cual se adhirió el entoncés estudiante de Letras Y Derecho; en los alrededores de la ciudad los integrantes del grupo del Norte se juntaban y paseaban a cualquiera hora del día o de la noche : el lento trabajar de una anciana, el andar meditabundo de los bueyes, por los caminos que orillan los ficus "melenudos", entre "huacas" Y "bloques preincai$\cos ^{\prime \prime}$, son otros tantos detalles que sitúan los poemas al par que aquellos nombres propios que señalan el camino de Trujillo a Chanchón, la ruinosa ciudad donde reinara el Gran Chimú La Grama, cancha de deportes a la salida de Trujillo, con su única tribuna, La Ramada (N. I., 4), Y más lejos el pueblo de Mansiche (N. 1., 1), cuyo pasado glorioso se remonta hasta la época de los Mochicas, reyes de "muertos dominios" y alfareros de insuperable calidad.

(4) La emoción humana de Vallejo, sensible desde joven a todas las miserias, empieza ya a manifestarse en el mismo, poema; Menocucho representa todas las empresns donde hay seres que trabajan y sufren injustamente : $L a$ hacienda Menocucho cobra mil sinsabores diarios por la vida". 
Entre los compañeros de Vallejo imperaba entonces el modernismo; solían designarse a sí mismos con nombres alegóricos y bautizaban igualmente con vocablos de mítica resonancia $\alpha$ las muchachas que los acompañaban: "Mirtho" era la amada del poeta, la cual no sólo dió su nombre a uno de los cuentos de Escalas Melografiadas, sino que probablemente inspiró también algunos o quizás la mayoría de los poemas de amor que encontramos en Los Heraldos Negros.

En 1918, cuando Vallejo, llegó a Lima, donde había estado en anterior oportunidad algunos años antes, tenía ya escrito gran número de los poemas que iba a reunir en su libra. Sin embargo, las impresiones urbanas, aunque en número limitado, marcan algunas de las composiciones más originales y entre las últimas escritas del libro: no sabemos si el suertero andrajcso que simboliza a Dios en La de a mil (5) es trujillano o limeño, pero la sensación de lluvia que confiere un tono característico a lis dos poemas, Heces y Lluvia, resume para nosotros en una sola nota de tristeza absurda e infinita, la atmósfera de la capital, nueva Bizancio (Idilio Muerto), tal como Vallejo la sintiera, añorando los "celajes" de su tierra natal.

\section{Biblio CIRCUNSTANCIAS "Jorge Puccinelli Converso"}

En Lima, Vallejo no tardó en ser acogido por las personalidades más destacadas que entonces ocupaban el nuevo ambiente artístico en trance de farmación. No conservamos prueba tangible de las repercusiones que la lectura o el encuentro de José María Eguren hayan podido tener sobre el poeta, ton diferente, de Los Heraldos Negros; en el texto mismo del libro tenemos en cambio el testimonio de la admiración que el jcren escritor confesaba por la obra y persona del viejo maestro González Prada quien había de morir en ese mismo año de 1918 : véase para mayor prueba la dedicatoria de Los Dados Eternos.

Pero quién más movía entonces el medio limeño era Abraham Valdelomar; sabemos que recién llegado de Trujillo Vallejo conoció a Valdèlomar en un café y que el Conde de Lemos después

(5) "La de mil" era la "gorda" de aquella época; correspondería a "la de un millón", en nuestros días. 
de estrechar la mano al provinciano le espetó una de esas ocurrencias con que solía desconcertar a los demás : "Ahhora, ya puedo decir en Trujillo que ha estrechado la mano de Abraham Valdelomar" (1). No fué Vallejo quién contó el encuentro a los trujillanos, sino el mismo Valdelomar en un viaje que hizo al poco tiempo por el Norte, cuando declaró al periodista de La Reforma de Trujillo encargado de entrevistarlo: "En Lima conocí al poeta César A. Vallejo, y hasta escribí algunas palabras en su elogio . . . Vallejo es un poeta en la más noble acepción de la palabra. Pienso ocuparme de su obra en detalle, cuando escriba el prólogo que me pidió para su hermoso y raro libro de versos Los Heraldos Negros . . ." (2). Declaración esta última que revela singular aprecio del artista ya consagrado por quien algún día había de eclipsar su gloria.

La llegada de Vallejo a Lima coincidió con las albores de algo nuevo en la vida literaria del Perú. Las manifestaciones iconoclastas de Valdelomar, si bien al principio habían provocado la ira o desprecio de los partidarios y cultores de la tradición, como los del director de Variedades, Clemente Palma, habían logrado finalmente introducir un elemento subversivo irrebatible que pronto terminaría con las posiciones hasta la fecha admitidas. El año 1918 señala la apoteosis de Valdelomar quien iba a desaparecer pocos meses después, de muerte prematura, en el preciso momento en que sus más antiguos $\mathrm{y}$ reacios adversarios renunciaban a discutirlo, y la gente tanto del norte como del sur o el centro del Perúl lo acogíá en forma triunfal durante la gira que había iniciado a través de la República. La aparición de El Caballero Carmelo, su libro de cuentos más famoso acababa de reconciliarle con todes aquellos a quienes antes irritaran sus "poses" $\mathrm{Y}$ extravagancias. El mismo Clemente Palma consentía tomarlo en serio y escribía en el número del 11 de mayo de 1918 de Variedades: "se le excusa por su talento"; en otra opcrtunidad hablaba también del más "teatrero" de los jóvenes escritores como de "quizá el único que tiene derecho a cometer una serie de tonterías y artificiosidades", ya que su obra lo acredita y él mismo se burla, afirma el crítico, de los estúpidos que pretenden seguir o imitarlo - salvedad por la cual Clemente Palma, al mismo tiempo que admitía la importancia del abanderado de las nue-

(1) Recogido por Alberto Hidalgo en Mucrtos Heridos y Contusos (Buenos Aires, I920); es de notar que al referir la anćcdota, por otros lados confirmada, Hidal-
go no menciona el nombre de Vallejo.

(2) Reproducido en Balncarios, No 364,26 de mayo de 1918. 
vas tendencias, podía continuar maldiciendo de las mismas, cuya inminente invasión lo preocupaba : "Nunca como ahora se ha cultivado el disparate, la vesanía y el hermetismo como formas y fondo de un arte nuevo, hecho a base de ignorancia, petulancia y desvergüenza . . . $\mathrm{Y}$ de vicios vergonzosos. $\mathrm{Y}$ de amoralidad absoluta. Y de bellaquería..."

Mientras tanto Valdelomar, curioso de cuanto signifícaba algo nuevo en el ambiente intelectual de la época, ejercía una influencia indiscutible en el campo más especial de la poesía, no tanto por su obra propia como por la atención generosa que dispensaba siempre a todas aquellos que habían de ser los poetas representativos de la generación siguiente. Ya anteriormente, al enfocar "la aparición de Vallejo en la poesía peruana" (3), señalé como aún para el lector mejor preparado el poeta de Los Heraldos Negros no podía aparecer en 1918 sino como un recién llegado entre varios otros que pasaban ccnjuntamente $a$ ocupar el primer puesto en el escenario artístico del Perú; nos conviene ahara insistir en ello. Efectivamente, en forma casi simultánea, se da ban a conocer en Lima poetas provincianos criginarios de los dos polos opuestos del país: paralelamente al grupo trujillano que más tarde vendría a denominarse "El Norte", se había formado en Arequipa uno, cuyo cabecilla, Alberto Hidalgo, acababa de fundar un revista local Anunciación al mismo tiempo, que en Lima se publicaba Colónida. Cinco años más joven que Vallejo, Hidalgo entregaba a la imprenta en 1917 un primer libro de versos llamado Panoplia Lírica, para el cual Valdelomar había éscrito una "Exégesis Estética' con tono evidente de manifiesto de la juventud.

Si bien el autor de El Caballero Carmelo nunca llegó a escribir el prefacio que había prometido a Vallejo para Los Heraldos Negros, podemos juzgar por la tendencia esencialmente polémica de dicha "exégesis" cual habría sido probablemente el carácter reinvidicativo de la introducción a los poemos de Truenos o Canciones de Hogar. Lo que Valdelomar más celebra en Hidalgo es la explosión de una personalidad nueva que se expresa sin traba de ninguna clase, en un medio, el medio peruano, en que de ordinario "la rebelión es casi un crimen"; hasta la fecha los jóvenes han demostrado constantemente una humildad exagerada frente a sus mayores la mayor gloria de Colónida, entonces ya desaparecida, fué, afirma su antiguo director, el haber levantado "la pasión iconoclasta contra la miseria colectiva....

(3) Artículo publicado en Centauro, No 9, Octubre-Diciembre, 950. 
contra el caciquismo mental"; la poesía de Hidalgo, "cálida aún y palpitante", significa asimismo una etapa fundamental en la rebelión a la vez que una hermosa expresión del arte moderno, del cual Valdelomar da en forma de ecuación, la definición siguiente :

"Arte moderno - Síntesis Máxima de la Naturaleza -i Exaltación Máxima de la Conciencia".

En cuanto al libro mismo de Hidalgo, anterior en un año a Los Heraldos Negros, refleja una inspiración en general muy diferente de la de Vallejo: obra compleja, contiene unos sonetos inspirados por motivos locales, en los que encontramos, aunque menos elaborada, una influencia de Herrera y Reissig paralela a la que estudiaremos por ejemplo en Nostalgias Imperiales; también unas composiciones amorosas de tonalidad igualmente modernista, pero las dos secciones más importantes del libro las constituyen La Religión del Yo (dedicada a González Prada) y Plus Ultra. La Religión del Yo viene a ser la afirmación en primera persona de una naturaleza violenta, orgullosa y triste, que se estima muy por encima de "los leyes al uso"; sin embargo, por más que a veces aparezca un humorismo a la moderna y asimismo podamas advertir la tendencia a ritmos menos rígidos que los tradicionales, es fácil comprobar cuanto debe semejante exaltación personal a una tradición en cierta forma romántica, que, en la época modemista, Chocano acababa de renoyar a su manera:

Yo nací de una quechuai yull español soldado, de un arrebato lúbrico y un beso enamorado..... Los hombres me aborrecen porque tengo talento, porque es un gran pecado saber sentir: |Yo siento!

(Autobiografía).

La novedad más chocante para el público contemporáneo se hallaba pues en la última sección señalada "Plus Ultra". Hidalga recoge en ella esa clase de sensibilidad moderna cuyo profeta europeo era el italiano Marinetti desde el año 1909, quien publicara en Milón el primer Manifiesto del Futurismo. Para el medio peruano el poema de Panoplia Lírica, titulado La Nueva Poesía, constituye a su vez un mamifiesto "futurista":

Ya soy un empresario vidente del Futuro.

Dejemos ya los viejos motivas trasnochados

y cantemos al Músculo, a la Fuerza, al Vigor 
Poesía es la roja sonrisa del Cañón;

Poesía es el brazo musculoso del hombre;

Poesíc es la fuerza que produce el Motor..

$Y$ en su adhesión à la fe futurista en la máquina y en la guerra, Hidalgo escribe simultáneamente una Oda al automóvil (que para Marinetti era "más hermoso que la victoria de Samotracia"), contándonos las emociones experimentadas al manejar " un Mercedes de 50 H. P.", antes de dedicar en plena conflagración mundial una Arenga lírica al Emperados de Alemania, Guillermo II, y entonar un entusiasta Canto a la guerra ("única higiene del mundo", Marinetti dixit) donde proclama los nuevos dogmas y las nuevas esperanzas:

Los cañones derrumban las viejas catedrales...

La guerra es como un brazo del progreso...

Bien sabemos que del alboroto futurista no queda hoy día casi nada, y su importancia es de orden ante todo histórico; los movimientos poéticos inmediatamente posteriores, si bien heredaron del grupo de Marinetti un desprecio profundo por las antiguas formas artísticas y una voluntad incontrastable de liberar la sintaxis y el vocabulario tanto como un espíritu de protesta il provocación y polémica, pronto abanclonaron por completo aquella moral y sensibilidad nueva que el futurismo se había propuesto imponer: los poemas de Hidalgo en esas condiciones no pasan de ser el testimonio de una época fugaz y sin descendencia. Los elementos nuevos que, según diremos, Vallejo ofrecía en Los Heraldos Negros no tenían nada que ver en cambio con las manifestaciones intempestivas de una escuela que creía poder sustituir, en poesía, la nostalgia por la alegría epiléptica del presente y la espera febril de un futuro destructor, peligroso y mecánico; representaban algo menos estridente pero al mismo tiempo mucho más profundo en definitiva, mientras que Panoplia Lírica, libro donde no subsiste ninguna zona de sombra $\circ$ misterio, apenas nos sigue interesando por marcar uno de los primeros gestos de ruptura de una juventud que se internaba por caminos nuevos con un entusiasmo caótico y no siempre afortunado en la elección de sus propios valores.

De todas maneras la obra polámica iniciada por Hidalgo al mismo tiempo que su obra creadora iban a tener el mérito de terminar con 
las glorias pasadas y consagrar definitivamente la preeminencia de los maestros del año 20 : González Prada, Eguren y Valdelomar (4).

La violencia polémica de Hidalgo estaba compartida en el mismo momento por quien había nacido igualmente en Ârequipa y se había manifestado junto con él publicando en 1918 un libro de versos bajo el título de Prometeo. El Prometeo de Alberto Guillén nos parece a distancia el único poemario exactamente ccntemporáneo de Los Heraldos Negros al cual podamos todavía referirnos. Con un Portico de Urquieta que saludaba en él la "resurrección de una poesía masculina, sana, pura, dura a trechos", el libro propugnaba una moral, la de una vida robusta, de cuerpo y espíritu en el esfuerzo $y$, la esperanza cotidiana. En realidad el título Prometeo es un símbolo, el símbolo del Hombre con $\mathrm{H}$ mayúscula, el Hombre consciente y fuerte, rebelde y exigente, cuya suprema expresión se realiza en el Poeta:

Vengo a exaltar al Hombre.. . a enaltecer la vida....

Mañana no seré ya un Hombre, habré pasado a la conciencia humana... Hoy no basta a los ojos de los Hombres

Ser un degenerado

Para ser un Poeta...

El poeta ha de ser el Hombre múltiple

Educador! Escultor! Creadorteca de Letras

A semejante afimacion de piedad humana, la cual reconcilia a Cristo con Satanás en la doctrina superior del "amor al Yo", no es difícil atribuir un origen indiscutiblemente romántico, que no hacía sino prolongar, confiriéndole nuevos matices al mismo tiempo que le comunicaba valores personales, escritores como Stirner, Nietzsche o Kipling citados varias veces por Guillén en los epígrafes de sus poemas. Pero por encima de las demás influencias oímos retumbar aquí el eco de Walt Whitman cantando la necesidad de engendrar hijos espléndidos 0 , como escribe Guillén, un hijo "ebrio de Instinto, ebrio de Fuerza, ebrio de Vida", un hijo en 'fin consagrado a la tierra; y es así como el poeta exclama:

Seremos dioses, Hombres...

Nosotros llegaremos a la dicha absoluta...

(4) Véasc el libro ya citado Muertos, Heridos y Contusos, publicado en Bucnos Aires donde había ido a vivir el autor de Panoplia Lirica. 
Por su "egotismo altruista" y terrestre, Guillén se relaciona con toda una corriente poética que entonces aceptaba la influencia y ejemplo de Whitman corriente cuyo alcance mundial había de ser subrayado algunos años más tarde en la Antología de los Poetas de los 5 Continenies publicada por Yvan Goll en 1923. Esa influencia 0 ejemplo tampoco ha marcado la poesía primitiva de Vallejo, quien sin embargo conocía como la mayoría de sus contemparáneos al poeta de los "hombros de pana gastados por la luna" (Lorca) (5).

Al contrario de la que ostentaran Hidalgo o Guillén en sus poemas mencionados, la originalidad del primer libro de Vallejo nada c casi nada debe a tal o cual movimiento meramente circunstancial de la poesía internacional en los años de la primera gran guerra de este siglo; las audacias de los dos arequipeños, por más desconcertantes que parecieran a los lectores acostumbrados a los primores modernistas, se adherían y atenían a una tendencia de poesía predicante y egolátrica, más novedosa que verdaderamente nueva, y cuya moda, por lo demás pasajera, no bastaba para ocultar sus límites y deficiencias. En cambio lo que había de inaudito en Los Heraldos Negros, si bien se apoyaba en un fondo cultural aparentemente menos revolucionario, el modernista, iba a resultar a la larga mucho más interesante y duradero. Efectivamente la tonalidad inconfundible que caxacteriza los trozos mejor logrados del libro procede y depende exclusivamente de Vallejo, quien, por el hecho mismo de haberse emancipado lenta y progresiyamenteinlogró conquistar una expresión genuinamente propia de la que ya nada ni nadie podría en adelante apartarle, mientras que Guillén y sobre todo Hidalgo empezaban a producir libro tras libro, sensibles a todas las influencias, sin encontrar jamás un tono o una inspiración profunda y realmente personal.

Por lo tanto la aparición simultánea de los poetas arequipeños y lel trujillano nas revela no tanto una coincidencia en el concepto del arte y la poesía cuanto un cambio de atmósfera en el ambiente cultural peruano, el cual no era inútil indicar antes del examen más detenido de Los Heraldos Negros.

(5) En el próloga que cscribiera para Trilce en 4922, Antenor Orrego nombra a Whitman entre los poetas que él y sus amigos recitaban en las playas vecínas de Trujillo. 
Ahora bien, el libro de Vallejo no arremete brutalmente contra las normas de la poesía entonces imperante; lo provechoso para nosotros es precisamente seguir en muchas de las composiciones un proceso de ruptura que lleva paulatinamente al poeta a la creación de un arte estrictamente adecuado a su experiencia de la vida y el universo. "Para vanguardistas, Los Heraldos Negros parecen claudicante rezago de la poesía vieja; aparecieron como libro atrevido ...". escribía Jorge Basadre en los años de Amauta: es desde ese doble punto de vista, de la tradición y de la novedad, como conviene entonces estudiarlos.

Sabemos que las primeras piezas fueron compuestas en el medio provincial al que Vallejo perteneciera ya desde el año de 1915. Los libros escaseaban en aquel tiempo en Trujillo, y durante las excursio. nes campestres o las tertulias (?) urbanas que ellos organizaban, los "bohemios" ponían en común sus descubrimientos y recursos; leían recitaban, comentaban; los pocos informes proporcionados sobre esas lecturas por algunos de ellos confirman ma línea general que ya podíamos deducir del examen interno de Los Heraldos Negros.

Rubén Darío seguía dominando la poesía de lengua españala; su nombre era el que volvía más a menudo en las conversaciones del grupo del norte; Vallejo particularmente confesaba para el autor de Canios de Vida y Espierañzat ancedeveción de lasque nunca renegará (en París todavía sus amiqos do oirónCerHeges repetir : "¡Rubén Darío es mi padre!"); tenemos que subrayar semejante parentesco ya que, si bien la primacía lírica de Dario era entonces indiscutible, Ia mayoría de los continuadores americanos se limitaban a reproducir la belleza pasajera y fácil de imitar de cierta manera de Prosas Profanas, mientras que Vallejo desde el principio identificaba más bien su angustia con la del poeta de Nicaragua, en aquella zona nocturna del alma en la cual lo acechaban los espantos y las sombras. En Retablo (Los Heraldos Negros p. 65) (6) aparece la nave sagrada de las Musas; el único pasajero identificado por su nombre propio es Darío, muerto precisamente en 1916 -"Dario de las Américas celestes" - brujo del corazón cuya figura altiva cruza el espa"

(6) Para las referencias a los textos poéticos de Vallejo utilizo la foliacion de la edición Miró (César Vallejo: Poesias Complelas, Buenos Aires, Losada, 1949), la cual encierra un numero apreciable de errores, pero es la única corricntemente accesible. 
cio con su lira de luto, eternamente triste en el suicidio monótono de Dios.

Pero por más que Vallejo reconociera en Darío un maestro y más aún tal vez un espíritu fraternal en el dolor, el poeta cuya influencia viene a ser primordial en el detalle de Los Heraldos Negros es Herrera y Reissig : el puesto de primer orden ocupado por el vate uruguayo en el modernismo americano no había sido todavía exactamente valorado; no por eso los poetas jóvenes de aquel tiempo dejaban de sentir su importancia y no pocas de las metáforas nuevas que desconcertaron $a$ los primeros lectores de Vallejo procedían directamente de la obra solitaria de un artista solitario que durante toda su vida había padecido de la "epilepsia de la metófora" y sólo en esa forma había salvado la irreductibilidad y la "inmunidad" de su persona en un ambiente hostil o irónico. El destino singular de aquel poeta no puede ser comparado sino con el de Saint-Pol-Roux, simbolista francés reivinàicado más tarde por los surrealistas, a quien en su libro Las Literaturas Europeas de Vanguardia (1925), el "creacionista" español Guillermo de Torre reclamará un poco como precursor; quince años más tarde el mismo crítico volvió a contemplar la personalidad de Herrera y Reissig en un prólogo a las Poesías completas del "lunático" de la "Torre de los Panoramas" (7): ahí con tono menas polémico que en 1925, Guillermo de Torre sitúa a Herrera en el momento en que vivió: "Su grandeza,J dicę Sólocádmite pariaadecon la de Rubén Darío", pero Darío, agrega luego, fué un poco más y también un paco menos que un poeta típicamente modernista; Herrera y Reissig en cambio es quien encarna la tendencia en su plenitud, con los riesgos mismos y los excesos constantemente redimidas por un prodigioso don verbal e imaginativo, al mismo tiempo que anuncia algunas de las novedades de la poesía posterior. El autor de Los Extasis de la Montaña, mal apreciado por el gran público, había sin embargo influído en muchos jóvenes escritores sudamericanos antes del creacionismo y la reivindicación de Guillermo de Torre; entre esos ultimos escritores, Vallejo parece ser el que mejor asimilara dicha influencia y la integrara en una experiencia personal.

(7) Dicho prólogo ha sido reproducido con ligeras variantes en el libro La Aventura y el Orden, Buenos Aires, 19irt. 
Los demás autores modemistas, y especialmente Leopoldo Lugones (8) quie leían o conocían los compañeros de la Bohemia Trujillana no tenían par cierto la misma importancia, pero si agregamos algunos poetas franceses, conocidos directamente 0 a través de traducciones: Baudelaire, Samain, Verlaine, Maeterlink (9), adimitimos que las lecturas conferían al ambiente espiritual del grupo norteño cierta unidad que no dejaba de reaccionar en la existencia cotidiana; (10) es curioso advertir por ejemplo cómo, unos treinta años después, un abogado de Trujillo ha sabido relatarnos en la siguiente forma una anécdota de la cual Vallejo habría sido el protagonista: un día, poco antes de anochecer, el poeta había salido de la ciudad acompañado del narrador, llevando precisamente, en el bolsillo un pequeño libro de Herrera y Reissig; de golpe se detuvo, contemplando los matices peculiares de aquel crepúsculo; luego, volviéndose hacia el "oriente", exclamó: "Con razón, Dios mio ¡Si es la luna que con una testa mágica mira desde el balcón de la montaña en que, enamorada del sol, a esta hora se levanta. Qué hermoso, qué encorntador coloquio de esos dos luminarios que se miran y que se hacen señas: el uno desde el hueco del mar donde se hunde y ella, la muy coqueta, desde la punta del cerro donde se despierta y surge con tamaña cara risueña..." Nos es permitido dudar de la escrupulosa autenticidad de las palabras proninziadasicel poeta segazamente no hacia tales frases al hablar, pero de todos modos el testimonio es a distancia característico de una atmósfera en la cual Vallejo se envolviera antes de desprender paco a poco de la misma los motivos de una poesía personal. No olvidemos que de vuelta a Lima, después de un viaje a Trujillo, Parra del Riego, al presentar en 1916 el vate provinciano al público capitolino (11), lo calificaba de "paisajista sentimental y sugeridor" y también "preciosista" - juicio que hoy día nos parece de lleno equivocado pero nos dá una indicación interesante tanto sobre

!(8) En su libro César Vallejo (New York, 1952, p. 49-50), el profesor Monguió ha insistido especialmente en ella; pero de todas maneras la influencia de Herrera y Reissig sigue siendo con mucho la más importante.

(9) Ilerrera y Reissig habia traducido a los dos primeros.

(ro) Un ambiente espiritual diferente por ejemplo del de Arequipa, 'doncle según vimos anteriormente, ejercían mayor influencia, al lado de los modernistas, Whitman y también los entonces más novedosos poctas futuristas.

(11) En Balnearios, 22 de octubre de 1916, La Bohemia de Trujillo. 
los comienzos del poeta, como sobre las condiciones generales del momento en que Vallejo iniciara su obra.

Por lo demás no es aventurado afirmar que, en un principio, la ambición consciente de Vallejo había de coincidir bastante con la de su amigo Antenor Orrego, el pensador del grupo, quién en una colección de aforismos titulada Notas Marginales (Ideología Poemática) (12) nos expone una estética, la propia y sin duda igualmente la de sus compañeros: el poeta, declara Orrego, recompone y unifica el universo; "el único pecado original es la limitación... Lo divino en nosotros consiste en aquella alada impulsión para trocarnos en Dios. ... Mi estética, es decir mi expresión personal, tiene como leit motiv que la preside la coordinación de los cuatro costados del hombre con los cuatro costados del universo..." La nostalgia y la invocación a la unidad que encontramos en varias de las composiciones de Los Heraldos Negros ("Oh Unidad excelsa... - Un latido único del corazón,- un solo ritmo: Dios..." presentan todavía un acento directamente relacionado con el de la época y el medio circundante.

Uno de los poemas de 1918, Retablo (el poema en el que $\mathrm{Da}$ río es evocado) nos señala una intuición del poeta y la poesía que nas confirma en la anterior opinión : no hablo ahora de aquel substrato de angustia obscura y definitiva que da a las estrofas un carácter particular, sino de la idea tradicional en el modernismo del papel de artista concebido comboun Cbrujo Cazue, un S'arcipreste vago del corazón" (13). Una jiea paralela, aunquan de estilo más caótico y ambicioso, va expresada en la dedicatoria de Los Heraldos Negros escrita en el ejemplar que Vallejo mandó desde Lima a sus amigos de Truji110: (14) "Los Heraldos Negros acaban de llegar... -anuncian de graneado: que alguien viene por sobre los himalayas y todos los andes circunstandiales- Detrás de semejantes monstruos azorados y

( 22 El libro fué publicado tan sólo en 1922 pero constituye un resumen de la filosofia estética de Orrigo y por lo tante recoge proposiciones que ya rigieron 'en los años anteriores.

(13) La expresión: "Dario de las Américas Celestes" puede ser relacionada con acuclla del mismo Darío en su poema al Rey Oscar: "mientras haya . . una América oculta que hallar. . . la imagen de la "nave sagrada" en la que se han embarcado los poetas tampoco es nueva y en la atmósfera de la primera estrofa podemos veŕ pasar como la sombra del "Barco del Dante" pintado por Delacroix.

(1.4) STe reproducido esa dedicatoria en mi artículo ya citado de "Mar del Sur", No 8. 
jadeantes suena por el recodo de la aurora su agudísimo y absoluto "solo de aceros".

A semejante idea de la poesía, la cual requiere una voluntad universal y artística de armonía y una auscultación inspirada del alma divina y humana, corresponde cierio "aristocratismo" de sentimiento $y$ expresión que vemos comprobado por el epigraie que encabezu la edición de 1918: "Cui potest capere capiat.- El Evangelio" (cf. asimismo la dedicatoria de Los Dados elernos a González Prada: "Para Manuel González Prada esa emoción bravia y selecta..." ).

Pero todas las fórmálas que acabamos de recordar, si bien nos ayudan a reconstruir un ambiente, no nos pueden servir mucho más tiempo: efectivamente el pensarniento consciente y critico, tanto co. mo la voluntad del poeta, son constantemente aventajados, en el caso de los creadores auténticos, por las realizaciones de la obra. La inspiración modemista, por to mismo que había recogido herencias distintas $y$ en cierta forma contradictorias -romanticismo, parnaso, simbolismo- y al mismo tiempo involucraba una gran pluralidad de temperamentos, podía por si sola indicar formas y motivos de inspiración bastante variados, pero no bastaba para traducir una experiencia hasta la fecha inaudita, y el libro de Vallejo, quién va afirmando progresivamente su libertad y a un tiempo descubre el fondo mismo de su personalidad, se sale de ella a cada instantes

\section{"Jorge Puccinelli Converso»}

\section{II.- CARACTERES FORMALES}

El título general, Los Heraldos Negros, tiene una resonancia netamente modernista (1) (cf. en Darío: Heraldos): los heraldos son simbólicos $y$ el adjetivo que los acompaña traduce en forma sugestiva, aunque bastante elemental, la amenaza que pesa en los mejores poemas del libro. Las composiciones más diversas resultan así mismo marcadas con un signo inequivoco, y la posición solitaria del primer

(1) El título del primer libro de IIidalgo: Panoplia Lirica es todavía más traticional a pesar de las novedades futuristas de gran parte de los poemas. El título de Vallejo tiene al menog la ventaja de expresal la nota afectiva dominante del libro que encabeza. 
poema cuyo título repite el título general acredita plenamente desde el principio dicha intención del poeta.

Los demás poemas (en total 68) van repartidos en seis secciones de desigual importancia, cada cual con un título colectivo que debería normalmente anunciar, como ocurre por ejemplo con Panoplia Lírica, el contenido general de la misma. Sin embargo, en la elección de esos títulos y la distribución de las poemas vemos ya manifestarse una ligera arbtirariecad o sea una ligera tentativa de independencia. La sección Nostalgias Imperiales presenta la mayor unidad, pues reúne poemas inspirados todos en los temas "localistas", pero el poema Los Arrieros que utiliza un tema idéntico se encuentra colocada en atra sección. En Canciones de Hogar, que constituye la última parte de la obra, están los poemas de inspiración íntima, familiar; ahora bien, el primero de ellos es un soneto, escrito en 1916 y sensiblemente modificado posteriormente, mientras que los siguientes representan una etapa de liberación mucho más avanzada en donde el tema sentimental se expresa de un modo completamente nuevo, que el título inofensivo de la sección dificilmente dejaba esperar. En cuanto al título de la primera parte, Platones Agiles ostenia cierta tonalidad parnasiana (2) imperfectamente relacionada con la inspiración de las piezas que incluye; no tiene otra unidad que la de reunir los poemas menos personales, los más cargados de intluencias.

Los títulos Buzos $y$ fruenos encierran, lo mismo que el título general, un valor simbólicojedeniraide lese concepto de la poesía al cual aludimos anteriormente, los "buzos" parecen indicar la investigación del terrible misterio circundante y de aquellas "hondas negruras del abismo" de las cuales hablara Rubén Darío; y los "truenos" deben ser los signos captados por aquéllos que, según otra expresión de Dario "auscultan el corazón de las tinieblas". En realidad en la sección Truenos podemos seguir de un poema a otro la altemancia de una interrogación sobre el problema de la vida y de la muerte (3) que se manifiesta todavía en una forma bastante intelectual ( $v$. gr. Los Dados Eternos), y de una intuición mucho más personal, en

(2) La unión de un substantivo (con valor plástico) poco usado cen un adjetivo que no le es ordinariamente aplicaclo indica una preocupación estilistica no muy acertada, pero conforme a una tendencia de la época modernista.

(3) Cf. en Rubén Dario las Dilucidacioncs que acompañan El Canto Errante: "La poesía existirá mientras exista el problema de la vida y de la muerte". 
la cual no cabe explicación alguna, del mismo problema (v. gr. El Pan Nuestro); en Buzos, sección muy breve, el vínculo que une entre sí los poemas resulta aún menos evidente. Bajo el título De la Tierra encontramos finalmente reuridos poemas de inspiración generalmente amorosa aunque otras composiciones de inspiración idéntica estén dispersas a través del libro entero.

Si nos referimos ahora a los títulos particulares de los poemas, advertimos que no siempre tienen un carácter idéntico; la significación de la mayoría de ellos tanto coma su pertenencia a una lirica ya tradicional son innegables, - trátese de los títulos puramente objetivos como Bajo los Alamos (cf. cualquier soneto rústico de Herrera y Reissig), Terceto Autóctono (cf. Dario: Tríptico a Nicaragua), Oración del Camino (cf. Chocano: La Canción del Camino), o de títulos con simbolismo erótico-religioso como Romería, Nochebuena, Impía, etc. Pero ya Fresco en su vaguedad deja de tener una relación precisa con los versos que encabeza; Babel no está muy da acuerdo a primera vista con el poema que lo acompaña, el mós breve del libro, el menos elaborado pues la sensación se trasluce en él directamente, en su estado puro (4); después de Rosa Blanca, el lector espera una composición del tipo de Rosada y Blanca de Herrera y Reisigg, pero se encuentra luegc con metáforas ("gato trémula del miedo", etc.) que recuerdan más bien una manera de Herrera completamente diferente,la tenebrosa; el título Heces introduce una tonalidad simbólica nueva, típicar de una fendencia fundamental en la obra posterior de Vallejo; finalmente, en los dos últimos poemas del libro, la emancipación se hace más radical: los títulos mismas son constituídos por sendas palabras inéditas, inventadas por el poeta: Enereida y Espergesia (cf. p. ej. en Trilce, 19: "Hélpide dulce"), de las cuales tos recuerdos mitoló que su sonoridad evoca en nuestra mente ciertos recuerdes mitológicos, evocación de todos modos imprecisa que confiere a las mencionadas composiciones una ambigüedad no completamente exenta de gratuidad; vemos asomar una forma nueva de verbalismo que tendrá más tarde mayor desarrallo, y no podemos dejar de pensar en el modo como el poeta en busca de título inventará el de su segundo libro,Trilce, cuyos poemas se distinguirán tan sólo por un simple número.

(4) El título Babel confiere entonces al poema una extensión bastante inesperada. 
Antes de iniciar el estudio detenido de los pcemas de Los Heraldos Negros, nos cabe seguir la liberación progresiva de la originalidad de Vallejo considerando rápidamente los medios técnicos que el escritor utiliza y trata de renovar a su manera: metros, estrofas, rimas o ausencias de rimas. El modernismo había enriquecido la métrica española con ritmos nuevos transpuestos del francés o descubiertos a raíz de las búsquedas personales de los escritores, como aquellos versos a base de grupos isosilábicos yuxtapuestos, ampliamente utilizados por Chocano; pero semejantes búsquedas y novedades, si bien ampliaban los recursos de la métrica tradicional, no dejaban de atenerse estrictamente al molde general de dicha métrica; González Prada se había contentado con soñar con un ritmo liberado de las argollas que lo entorpecían y siempre existían metros y estrofas regulares en la poesía de Dario; por su parte Herrera y Reissig circunscribía sus audacias metafóricas más desconcertantes dentro de los límites en extremo rígidos del soneto, variando tan sólo la extensión de los metros (algunos de sus sonetos han sido escritos en versos de 8, otros en versos de 11,14 y 16 sílabas) y la disposición de las rimas. Vallejo no escapa de una vez a las necesidades formales de la poesía de su época pero lo va haciendo desde el principio en forma progresiva y definitiva.

De los 69 poemas de Heraldos Negros, 18 se someten todavía a las normas del sonéto; dl de decellesli(AusentescBajo los Alamos, Setiembre, los 4 de Nostalgias Imperiales, los 3 de Terceto Autóctono y Unidad) escritos en versos de 11 sílabas; 2 (El poeta a su amada y Capitulación) en alejandrinos clásicos, 3 (Nochebuena, Sauce, Amor) adoptan el verso francés de 12 sílabas y Lluvia el verso de 9 sílabas, ya utilizados, tanto el uno como el otro, por los modernistas. Pero en una oportunidad (Idilio Muerto) Vallejo toma una libertad excepcional en la escritura de un soneto: la disposición de las estrofas y las rimas es todavía tradicional mas los versas presentan extensiones desiguales (14, 11 ó 17 sílabas); el ritmo se ciñe a la intuición; y en el campo ortográfico, los signos de interrogación que lógicamente se esperarian en las tres primeras estrofas han sido substituídos por simples puntos y comas.

Aparte en los sonetos de forma regular la elección de las rimas revela igualmente un principio de emancipación de la estructura exteriormente conservada : en El poeta a su amada la misma palabra, "beso", 
vuelve tres veces como rima en el curso de los dos cuartetos; enCapitulación $y$ en Setiembre algunos versos riman $y$ otros nó (5).

Cuando Vallejo no adopta para sus poemas una forma tradicional fija es evidente que su libertad frente $a$ los ritmos y las rimas se afirma de un modo mucho más radical. Deshojación Sugrada está com. puesto con versos endecasílabos reunidos en ruartetos de rimas cruzadas, pero en Nervazón de Angustia, los cuartetos esta vez a base de alejandrinos, han dejado de presentar rimas regulares: en las 2 primeras estrofas, riman unicamente el $2^{\circ} \mathrm{y}$ el $4^{\circ}$ verso, en la estrofa 4 , riman el $2^{\circ} \mathrm{Y}$ el $3^{\circ}$; en cuanto a la estrofa 6 , permanece incompleta: después de empezar como las anteriores por el alejandrino termina bruscamente con un $2^{\circ}$ verso endecasilábico ;el poema se interrumpe y recae, rítmicamente sin acabar, traduciendo de esa manera la preeminencia de la emoción subre la preocupación puramente formal (6). En Las Piedrás al contrario la última estrofa se prolonga por la dob!e repetición de una misma palobra piedras", mientras guo, en el curso del poema, la $3^{a}$ estrofa emplea la serje de rimas $\alpha^{-b}-b-a$ en lugar de la que rige las demás estrofas ( $a-b-a-b)$ (por lo demás "nada" rima con "nada" y "piden" con "piden").

Oración del Camino se imicia con una estrofa cuya forma parece que ha de prolongarse en los siguientes : 4 versos de 11 seguidos de 2 versos de 7,105 cuales en lon $2^{a}$ estrofatrepiten los de la ist como estribillo, pero la $3^{\text {a }}$ estrofo es ya muy diferente de las que preceden e incluye además un verso de 8 silabas que rompe la unidad armónica. La disposición de Mayo o de Aldeana -estrofas irregulares basadas en la alternancia de los endeca y heptasílabos- es tradicional en esa clase de poemas desoriptivos, pero la introducción de versos de 7 sílabas entre versos de 11 ien Medialuz tiene un significado mucho más preciso; lo mismo sucede en EI Palco Estrecho, Verano o Deshora (7). La alternancia de los versos de 12 y 6 sílabas (practicada por los modernistas) en Amor Prohibido y en Para el alma imposible de mi amada, o de 10 y 5 sílabas en Impia no presenta nada especial-

(5) La disposición de las rimas de los cuartetos es, en 15 de los pocmas, la siguiente: a b a b; una sola vez (Bajo los Alamos) encontramos lit disposición mís clásica: $a b$ b a.

(6) En el 'soneto de Dario:Melancolía (Canlos de Vida y Esperanza) podemos encontrar un precedentc todavía timido.

(7) Cf. en Idilio Muerto y La Voz del Espejo, poemas en los duales dominan los versos de 14 piés, la aparición de cndeca $y$ heptasilabos. 
mente original; pero en El Pan Nuestro, en Absoluta, donde volvemos a encontrar la alternancia dominante de los endeca y heptasílabos, aparece bruscamente un verso de otra medida; en Rosa Blanca el ritmo principal del heptasílabo sufre no pocas dislocaciones. Finalmente en poemas como A mi hermano Miguel o Enereida la extensión y disposición de los versos no depende sino del dictado sentimental que se proponen expresar; puede ser también que encontremos todavia en ellos apariencias de rimas pero estas resultan meramente ocasionales, pues la rima, como ya lo hemos apuntado en ejemplos anteriores, empezó a deshacerse para luego desaparecer conforme la métrica se volvía menos estricta.

En Mayo o Aldeana todos los versos siguen rimando, pero en La voz del espejo solamente la mitad se someten a la regla y además en un orden mal definido; el lecter siente que el poeta va desinteresćndose de las antiguas estructuras y dispone rimas sin mayor esfuerzo ahí donde ellas aparecen por sí solas y en la forma como se presentan; en otras partes se contenta con vageas asonancias, las cuales a su vez terminan desapareciendo. Al comienzo de EI Pan Nuestro las rimas son todavía muchas : "amada, cruzada, encadenada; queảos, viñedos (con la asonancia: luego): luz, cruz"; luego se van haciendo cada vez más raras hacia la conclusión : "café, iré (?); perdón, corazón" (8)

Lo esencial, la constituye en adelante la expresión humana fuera de toda obligación exterra yulformal: iclabdorde la supervivencia de la rima en el mismo poema El Pan Nuestro, la reaparición en la última estrofa de palabras, temas y hasta de versos del principio confiere a la composición una unidad especial que las antiguas leyes prosódicas no eran suficientes para crear. Cuando examinemos separadamente cada poema tendremos que insistir más de una vez en este carácter nuevo y que pronto había de ser permanente en lo poesía de Vallejo.

Por ahora nos basta advertir que aquella emancipación progresiva de la técnica que acabamos de señalar, paralela a una motivación interna de los poetnas cada vez mús personal, si bien no se manifies-

(8) Antes de concluir con las características técnicas, convienc por lo incnos senialac el unos cuantos poemas la abundancia de palabras agudas como diltimas palabras de los versos; de ahi en mís de una oportunidad cierta sensación de dureza o más bieł de implacabilidad. 
ta con toda claridad en una lectura seguida del libro en el cual los diferentes trozos están dispuestos según un orden distinto del de su composición, está en cambio confirmada por los pocos datos históricos que podemos aducir al respecto: a falta de versiones manuscritas er a preciso buscar especialmente en La Industria de Trujillo y en el semanario Balnearios de Lima (9) - años 1916 y 17 - el estado primitivo de algunas composiciones de Los Heraldos Negros (10); el mero cctejo de las versiones publicadas en los aludidos periódicos y de las recogidas más tarde en el libro establece en forma palmaria cómo las últimos meses de 1917 y los primeros de 1918 han sido decisivos en la conquis. ta que hizo Vallejo de una manera poética propia y auténtica.

En primer Yugar todos los poemas encontrados antericres a aquelia fecha están entre los más influenciados por Dario y Herrera y Reissig; por otra parte las variantes que existen entre aquellos textos y los publicados en 1918 confirman la misma evolución: el pcema Hojas de Ebano llevaba en 1916 el lítulo mucho más directamente narrativo do Noche en el campo; la supresión de unos 20 versos y la modificación de otros, precisamente los de influencias más marcadas o los más flojos y torpes, significan un paso adelante hacia una mayor originalidad; en Pagana por ejemplo la desaparición de giros puramente lógicos (como... cual... tal...) revela un progreso en la elaboración de la metáfora anteriormente carente de gracia y soltura; en Encaje de Fiebre el cambio completo del ultimo yerso depara al sonetc una tonalidad que permite introdidiflo (aunque todavid con cierta inhabilidad) en la misma sección que poemas de una técnica muy diferente; por fin en 1918 Vallejo reúne a veces dos palabras estrechamente vinculadas por el sentido para formar una sóla palabra nueva (11), cosa

(9) Publicación literaria de Chorrillos, Barranco y Miraflores; una sección de la revista daba a conocer las jóvenes poctas provincianos.

(10) Advertimes en esos primeros poemas el uso abusivo de las puntos suspensivos $y$ admirativos que Herrera $y$ Reissig va habia utilizado en gran cantidacl. Pero lo más probable es que semejante catracteristica representaba, mís one una simple imitación, la presciencia, por parte de vallejo, de la insuficiencia de las formas tradicionales para reproducir los movimientos de sti intuición poética, y la necesidad de rmmper, aunque en forma todavía torpe y primitiva, los ritmos establecidos. He reproduci. do en el artículo citado de Mar del Sur (No 8) los textos acuí aludidos.

( I ) Procedimiento en el que está quizás el origen de muchas audacias y creaciones verbales de Trilce. 
que él mismo no se atrevía a hacer todavía en las primeras versiones : "Ncser" (Encaje de Fiebre) se escribe siempre "no ser" en 1916 y "viernesanto" (El poeta a su amada), "viernes santo" en 1917.

\section{III.- EN TORNO A LA INSPIRACION AUTOCTONA}

Partiendo de las observaciones formales que acabamos de hacer, pademos ahora considerar los poemas de Los Heraldos Negros en su estructura y su significación propias.

La influencia de Herrera y Reissig en realidad no se manifiesta en forma directa $y$ absoluta sinó en el soneto "Bajo los álamos" ( $p$. 28); el tema pastoral, la atmósfer a crepuscular y la interpretación imaginativa (acercamiento de los planos humano, vegetal, animal o astral) pertenecen por completc a la manera de Los Exiasis de la Montaña poemas aparentemente objetivos ya que proceden de la visión de un cuadiro natural, pero que saben realizar desde e! principio lo que G. de Tarre llama "una subjetivización de la realidad", carácter suficiente para separar radicalmente la poesía cle Herrera de la de Albert Samain que sin duda le inspirara sus temas y motivaciones.

Los "álamos de sangre" de Vallejo, "hieráticcs bardos prisioneros", tienen su origen inmediato en "el sauce como un viejo sacerdote gravemente inclinado nos unía" de Herrera (El sauce) (cf. igualmente: "tres álamos en éxtasis" (La noche); "las greyes de Belén en los oteros" y su rumiar litúrgico recuerdan los 2 versos siguientes de los Extasis, amén de otros ejemplos similares: "y te bendice el beato rumiar de los vacunos / que sueñan en el tímido Bethlém de los establos" (EI domingo) (podríamos pensar igualmente en el poema de Lugones, Gloria otoñal) (1); más allá los dos últimos versos del segundo cuarteto vinculan esta inspiración, al mismo tiempo pastoral y religiosa, que tantos poemas sugirió al bardo uruguayo con otro rasgo, igualmente frecuente, en la obra de Herrera : la fusión del rostro humano extracrdinariamente ampliado y de los cuerpos celestes humanizados (cf.

(1) Es cosa conocida que en la época de Crepuisculos en al Jardin la obra de Lugonss fué un tiempo paralela a la de Herrera y Reissig, hasta el punto que los críticos siguen discutiendo cual de los 2 poetas inspiró al otro. 
Herrera: "te besó el lucero- se durmió la tarde en tus ojeras- en nuestros ojos un lucero sorprendía una lágrima", esct - passim); los "martirios de la luz" pertenecen a aquella espiritualización de los fonómenos naturales y particularmente del crepúsculo qque encontramos por ejemplo en expresiones del tipo: el ocaso traspasado de ultratumba (Herrera : El genio de los campos; "postrero" es una palabra que Herrera gusta como buen madernista prefiriéndola $\alpha$ "último" : "pos" trer arranque", "lágrima postrera", elc.) y "las esquilas" también representan un papel importante en sus poesícis de tema campestre. En cuanto a la elaboración de la imagen: "las esquilas se otoñan de sombra", podemos cotejarla con tal o cual expresión herreriana, v. gr. "sus ojeras otoñales de bruma" (Berceuse blanca); la personificación do un fenómeno natural, el instante "Iqbraclo en orfandad" tiene ctsímismo precedente en "la cristiana viudez de aquella hora en la campaña" (Herrera : El crepúsculo del mortirio)

El último verso del poema resultan si cabe, todavía más carcicterístico: varios poemas de Herrera terminan como aquel del cual nos ocupamos actualmente en el ladrido de un perro diversamente interpretado (véanse particularmente: La noche y El entierro; en el último verso de La sombra dolorosa reaparece todavía el ladrido pero esta vez atribuído con más audacia metafórica a un tren que aulla de dolor en la lejanía) jel mismo Valleje poe etrg parte reintroducirá un motivo semejante al final de otro de sus sonetos: "cavarón los perros, cullando, un adiós! "(Éruce).

Bajo los Alamos nos ofrece una imagen idílica cuyos elementos están sacados de la realidad, pero que de todas maneras no puede ser situada en un lugar geográficamente preciso, determinado. Es sin embargo con ese soneta con el cual debemos relacionar los poemas de inspiración autóctona que encontramos en Los Heraldos $\mathrm{Ne}$ gros. Todavía fuertemente influenciados por Herrera $Y$ Reissig en sus procedimientos y metáfaras, ellos peruanizan al mismo tiempo Ios motivos $y$ escenarios, $y$ por lo tanto exigen del artista una definición más precisa. No les vamos a atribuir un interés poético de primer orden pero es innegable la importancia histórica que tuvieron y siguen teniendo en una valoración de la poesía de aquellos años. La poesía indigenista de la época siguiente (Alejandro Peralta, elc.) 
había de recurrir a una técnica sensiblemente diferente; de todos modos las composiciones de Nostalgias Imperiales señalan un momento, aquel en que los motivos locales invaden por primera vez en forma tan directa la inspiración lírica; advirtamos sin embargo que al escribirlos Vallejo se somete a las solicitaciones de la época, impresionista y modernista.

El título de uno de los primeros libros de Chocano : En la aldea (1895) podría a primera vista inducimos a error: los poemas -mediocres - de ese libro de juventud se adhieren en realidad a una manera definitivamente condenada; a lo más cabe señalar en el título Aldeana, de Vallejo, un lejanc recuerdo del título de su antecesor (Terceto autóctono también se llamaba en un principio Fiestas Aldeanas). Pero en algunos poemas de Valdelomar (v. gr. el soneto que empieza : "sobre la arena mórbida...") aparecen ya lo motivos familiares de un paisaje costeño del Perú, directamente mirado sin necesidad de verlo, como lo hacían los poetas anteriores, a través de modelos literarios europeos. Más característicos $\mathrm{Y}$ al mismo tiempo presentando más parecida con los de Vallejo, unos poemas de Panoplia Lírica, el libro de Hidalgo (2), contemporáneo de Los Heraldos Negros, nos indican una nueva orientación (3): los campesinos son ahora unos "cholos" con "ponchos" y las campesinas unas "cholas" en "faldas de franela", que se embriagan con la "chicha"l local; el sol al ponerse parece un Inca en su imperial majestad; y las metáforas, aunque menos elaboradas que las de Nostalgias Imperiales, recuerdan igualmente en $\mathrm{mu}$ chos detalles la manera de Herrera y Reissig.

(2) Valdelomar es un costeño, Hidalgo un serrano (las secciones de su libro a las cuales nos referimes se llaman Visiones de la Sicra y De ticrra adentro); la poesia indigenista de Peralta $y$ sus discipulos será aún más deliberadamente scrrana (con un fin asímismo polémico). Los poemas "localistas" de Vallejo, aunque inspirados sobre todo por las visiones serranas de la niñez, no desprecian tampoco los cuadros costeños de la juventud, y el "valle" de Oración del camino viene a ser como el lazo que une en vcz de oponerlos, ambos medios naturales cuya presencia el poeta siente con igual intensidad.

(3) En su libro "César Vallejo" (New York, 1952, p. 50-5I) Luis Monguió, al cvocar en Los Heraldos Negros la peruanización de temas y motivos modernistas, inicia un paralelo con La Sangre Devota del mejicano López Velarde. Prefiero insistir en ejemplos exclusivamente peruanos, pero ambas clases de ejemplificación comprueban una vez más la fuerza del llamado "aire del tiempo" en la transformación de las formas $y$ tendencias artisticas. 
Las composiciones de Vallejo por consiguiente no nacen en forma aislada, pero su mayor cualidad técnica y la emoción mús permanente que las sostienen acreditan de todas maneras el papel precursor que se les atribuye. Por lo demás, si bien ocupan una situación central en el conjunto de Lus Heraldos Negros, esos poemas distan mucho de ser los característicos del libro de 1918 y se encuentran en su mayoría entre las piezas más antiguamente escritas: Aldeana, por ejemplo, fué publicada en Balnearios a principios de 1916 y, en el transcurso del mismo año, se publicaron también las primeras versiones de Hojas de ébano y Terceto autóctono.

Varios testimonios concuerdan en ver en "Aldeana" (p. 51) el poema más antiguo de Los Heraldos Negros; sea lo que sea, el estado de dicho poema no ha variado desde enero de 1916 hasta la publica. ción de 1918; su técnica es tradicional y su contenido igualmente descriptivo; el plañido de la "quena" y la modulación del "yaravi" cons" tituyen las únicas notas locales que permiten situar la escena; el ambiente campesino, bíblico y litúrgico, con los detalles que lo caracterizan (esquilas que se derraman en el aire, animales y naturaleza humanizados por los adjetivos que los califican, etc.), se identifica con el ambiente de Los éxtasis de la montaña; el crepúsculo es un crepúsculo simbolista; laGíniónadel palabras (Colores y aspectos) de resonancia típicamenteg modernistal ("Mustiá, Strágancia, gualdo", etc.) con otras palabras de improviso creadas por el poeta ("dondonea") existe ya en Herrera; la única metáfora un poco atrevida de éste poema todavía tímido: "un gallo... aleteando la pena de su canto" tieno en Herrera igualmente antecedentes aún más expresivos (v. gr.: un "amasijo de hogaza que el instinto del gato incuba antes que el horno" (El domingo). Lo que confiere a ese primer poema un acento de todas maneras ya vallejiano, es la intervención del poeta: "de codos yo en el muro..." (Herrera nunca interviene en sus cuadros rústicos) $y$ el tono particular del "idilio" impregnado de principio a fin de una tristeza propia y de un dolor secreto que pronto habían de encontrar una expresión más nueva.

Los sonetos de Nostalgias Imperiales (p. 42) y Terceto Autóctono (p. 46) en virtud misma de su forma y de la mayor riqueza' en metáforas ве emparentan más directamente que Aldeana con los cuadros análogos de Herrera y Ressig, pero al mismo tiempo la "peruanización" 
está en ellos mucho más avanzada: el impresionismo inicial (4) ("El campanario dobla... Madrugada... Van tres mujeres... silba un golfo...", etc.) es constantemente renovado por la facultad creadora del poeta, la cual saca de los elementos locales la materia de imágenes oxiginales. Respecto al verso: "Ia niebla hila una venda al cerro lila ..." ya hemos oído algo parecido en Herrera (" el Hada neblina" abre "su palacio de algodón", "fuma el opio... de su cigarro glacial" Esplin; "el Hada neblina" abdica "su corona de algodón" - La ausencia meditativa; véase también "Tirita entre algodones húmedos la arboleda" - La flauta). En cuanto al "cerro lila" su color es tipicamente modernista (por ejemplo Herrera: "el aire lila"), pero inmediatamente éste mismo "cerro" es comparado a una enorme vasija prehispómica. a un "huaco gigante". Los álamas, "bardos prisioneros", de Bajo los álamos, reaparecen pero transformados en el árbol característico del paisaje peruano, el ficus: "Hay ficus que meditan, melenudos trovadores incaicos en derrota" (el sustantivo "trovadores" no es del todo apropiado pero lo importante es la intención de trasponer la realidad inmediata: en Hojas de Ebano tendremos por ejemplo "los viejos alconfores que velan... con sus ponchos de hielo").

De la misma manera los bueyes han perdido su "apastólica dignidad" (Herrera: La misa cándida) para adquirir el andar meditabundo de ancianos jefes del antiguo Perú: "como viejos curacas van los bueyes". Las campesinas ya no son "zagalas de la tradición españclar, sino "pallas" Jincaicas cyinel liclban, qué Herrera personificara como pastora en uno de sus poemas ( $E l$ alba) se identifica ahora con una aldeana netamente peruana que arremanga sus numerosas polleras para arremeter a bailar la danza de la sierra : el huayno (5).

Los recuerdos culturales se transmorman así mismo al contacto del medio ambiental y de una tradición hasta la fecha mediocremente utilizada: el sincretismo de las dos tradiciones, la bíblica y la indígena, sincretismo vívido en el culto del apóstol Santiago ("El moderno diossol para el labriego") se elabora en los poemas en medio de las influencias literarias: el crepúsculo de Mansiche sugiere la nostalgia

(4) Está relacionado con la introdtcción de expresiones familiares ("echa una cana al aire...") y de fragmentos hablados ("mañana que me vaya se lamenta un Romea. .. ").

(5) Simultáneamente se entreveran el color de la aurora $y$ el de los vestidos femoninos: "un huayno azul", "remanga sus pantorrillas de azafrán la Aurora" (cf. Herrera: Octubre que llora "sus cabellos de mítico azafrán"-Oioño). 
de los viejos imperios vencidos por la Cruz, pero al mismo tiempo el poeta llevado de sus lecturas escribe respecto a ese mismo paisaje que parece "un opúsculo bíblico que muriera en la palabra / de asiática emoción de este crepúsculo" (cf. Herrera: "Es una ingenua página de la Biblia el paisaje" -El teatro de los humildes), y los elementos sacados de la realidad -colores y ademanes : el color dorado de la bebida y el ademán acaso ritual de los bebedores- se someten a su vez al vocabulario litúrgico de la tradición literaria para suscitar expresiones de este tipo: "La eucaristía de una chicha de oro". La dignidad artística es en esa forma atribuida a la materia lccal, histórica o vivida (6).

En cuanto al mismo modo de "poetizar" ya sabemos de donde procede, - trátese de la personificación de abstracciones temporales: "la hora en rubor que ya se escapa" (cf. Herrera: "por la teja inclinada... descienden en silencic las horas" - La huerta), de la adjetivación nueva por transposición: "caldo madrugador" (cf. Herrera: "madrugadora leña" $\longrightarrow$ El alba; es lambién de tipo idéntico: "ruido aperital" y en Mayo encontraremos : "humo aperitivo de gesto"; en relación con otro orden de realidad leemos igualmente: "las viudas pupilas de los bueyes" cf. Herrera: "ojos viudos de cierva" - La noche), o la elaboración de las imágenes ("la chicha al fin revienta en sollozos, lujurias, pugilatos" $f$ las actitudes de los borrachos que han tomado con exceso la bebida dorada son atribuidos directamente a es. ta última; (cf. Herrera):gqa Vendinili abre Sus "Sojos glauccs" - La vendimia; en los declos de una anciana, el huso que ella tiene "trasqui-

(6) El poema "Mayo" (p. 49), cuyo valor propiamente artístico es mediocre, nos ofrece un ejemplo todavía bastante torpe de aquella integración de los seres $y$ lak cosas directamente vistos en el marco de una pastoral impregnada de la atmósfera cultural modernista; los versos que evocan la figura de Ruth pertenecen a un simbolismo amoroso tradicional (en cuanto a la expresión: "hcbraica unción", véase por ejemplo Herrera: "unción islamista") ; los jóvenes campesinos siguen llamándose "zagales" y "zagalas" (una "zagala" que llcra un yaravi"!!!); sus actitudes son interpretadas en un lenguaje complicado e inhábil, y cuando los designa en forma más precisa, el pocta, adulterando la actualidad y la localización de la visión, les atribuyc nombres mitológicos: "Venus pobre. . Aquiles incaico del trabajo..." (cf. Tercelo Autíctono: "Un Romeo rural"); el perro ofrenda al "floreciente dia" un "himno de Virgilio", y el indio abuelo fuma en medio de un crepúsculo modernista color de rosa, mientras el humo de su pipa, al tiempo que parece surgir de un huaco de epopcya, representa el aroma de místicos lotos y el "hilo azul de los alientos muertos" (cf. Herrera: "cl humo de las muertas ilusiones, hilo a hilo, subia..."-La vejez prematura). 
la la lana gris de su vejez": una materia, la lana, y un estado humano, la vejez de quién está hilando son vinculados de la misma manera que en Herrera donde una campesina, mientras va ordeñando su vaca, "ofrece la leche blanca de su plegaria" -El Alba).

Notemos asimismo que Vallejo en los sonetos aludidos domina perfectamente la materia y técnica que ha escogido: en el poema dedicado a la bebida y a la embriaguez (Terceto Autóctono) por ejemplo el río humanizado ( 7 ) ccmo en Herrera o Chocano se ve además, caracterizado por un adjetivo que lo integra directamente en el ambiente propio de la composición : "lejos el río anda Borracho".

En el poema anterior (T. A. 2), del cual hemos encontrado una versión primitiva, el empleo de una variante nos ayuda a captar el trabajo de corrección y perfeccionamiento realizado por el poeta; en 1916 leíamos: "Y el salmo del crepúsculo reviste de martirios de sangre el casería" (cf. Bajo los Alamos) imagen de cuño modernista sin originalidad propia e inmediatamente comprensible; en 1918 los 2 versos se han transformado en: "El ojo del crepúsculo desiste / de ver quemado vivo el caserío"; bajo la influencia más profundamente asimilada de Herrera y Reissig (cf. en éste último: los ojos de la noche, las del alba, etc.) la espiritualización del crepúsculo ha sido completada y la imagen más elaborada capta con acierto un momento más fugaz y casi imposible delfijá, elmomento preciso en que la noche aventaja al día, el cual brilla sim embargo, antes de morir, con sus fuegos más espléndidos. (8).

Simultáneamente la gran libertad verbal que triunfará en Trilce hace sus primeras y tímidas apariciones: Herrera no vacilaba, cuandc era necesario, en crear, a partir de los substantivos correspondientes, los verbos que le hacían falta ("epilepsiar, wagneriar, atempestar"

(7) El procedimiento de humanización de la naturaleza pucde presentar extremos caricaturales coma: "el mar labrado en su máscara bufa de canalla / que babea y da tumbos de ahorcado"; se advierte aquí una coincidencia con la manera tenebrosa de Herrera y Ressig (cf. por ejemplo: "El mar, como gran anciano, / lleno de arrugas y canas, junto a las playas lejanas, / tiene rezangos de anciano" - Desolación absur(da-); es interesante comprobar una vez más en los primeros poemas de Vallejo (y hasta en las composiciones de forma perfectamente definida) la fusión o combinación de influencias diversas, la cual señala un primer momento en la liberación del poeta.

(8) Hay que indicar asimismo las variantes existcntes entre las 2 versiones de Hojas de Ebano (por ejemplo, en la primera estrofa). 
etc.): Vallejo sigue su ejemplo ("enrosariar, aquenar (9): en la versión de 1916 semejantes audacias no existian todavia), y desde entonces empieza a llevar más lejos la licencia creadora: escribe 'aperital" en vez de "aperitivo" (cl. Mayo: "epopéyico" en vez de "épico"), y de un modo aparentemente más gratuito (ya que ambas expresiones se equivalen desde el punto de vista métrico), pero llevado de ma nuova lógica poética, "se aperfila" en vez de "se perfila" (en 1916 leemos todavía "se períila"; posteriormento ha sido calcado sobre la última palabra del verso que precede : "se aterciopela").

Pero lo que más ha atraído la atención de los críticos apresurados, en los poemas que evocamos, es la declaración del primer cuarteto de Nostalgias Imperiales: ". . y yábrase la raza en mi palabra". ¿De qué raza se trata en el presente/ caso? El concepto de raza es uno de aquellos conceptos mal aclardas y por eso mismo abusivamente utilizados en las más confusas polémicas; convendría por ello examinarlo nuevamente, sobre todo al tratar de una poesía cauténtica cque en definitiva poco tiene que ver con cualquier clase de conceptos. Para Mariátegui la voz de Vailejo se confunde con la voz del indio; para otros es la expresion idelicholocadosenociones distintas que a veces coinciden literariamente, pero que conviene dejar de lado por ahora para atenemos exclusivamente $\alpha$ los textos del poeta $\alpha$ lo que puedan revelarnos.

Dario había hablado anteriormente de la raza pero el concepto que de ella tenía parece haber variado sensiblemente desde el solemne llamado de la Salutación del optimista ("Inclitas razas ubérrimas, sangre de Hispana fecunda... Latina estirpe", etc.) hasta la reinvindicación del mestizaje, la afirmación, si bien generosa, bastante vaga de la "raza total" que encontramos en Raza (Poema del otoño) : "Juntos alientan vástagos/ de beatos e hijos/ de encomenderos/ o de soberbios indios". Chocano a su vez no nos ha escatimado las declaraciones de sincretismo americano: "Soy el cantor de América autóctono y salvaje... La sangre es española e incaico es el latido... Y así soy, en las pompas de mis cánticos regios, / algo precolombino $\mathrm{y}$

(9) En cambio "tahuashar" (Hojas de Elano) no es una creacion sino una palabra del vocabulario regional, de raiz quechua. 
algo conquistador...". Hijo del Sol, de la España y de la Cruz, "los virreyes, los incas y los conquistadores" vuelven a vivir en sus cantos lo mismo que en sus venas.

¿Qué es lo que nos dice Vallejo ahora en un poema enumerativo ("Huaco", p. 48), cuya presentación tiene algo similar por ejemplo con Los tres reyes magos de Darío, mientras que la inspiración es totalmente distinta y el simbolismo cristiano está substituído por un simbalismo prehispánico? El poeta ahí se identifica con los animales sagrados que los antiguos alfareros de su tierra representaban en los huacos: el ave fabulosa, el coraquenque, y luego el cóndor, la llama, el puma, animales todos que han martirizado deliberadamente unos hombres barbudos y despiadados llegados de tierras lejanas, aquellos mismos extranjeros cuya "necedad hastil" tan sólo ha triunfado con el socorro sangriento del "latino arcabuz". En los dos últimos versos surge una esperanza, pero el tono dominante es el de la blasfemia y rechazo frente a todo lo cristiano y español (los "Coricanchas" han recibido el bautismo pero ha sido un bautismo "de fosfatos de error y de cicuta" (cf. en Nostalgias Imperiales: la "rancia pena de esta cruz idiota"), aunque en el momento más patético de su negación Vallejo siga acudiendo, para mejor definirse, a imágenes de origen evangélico: el joven cóndor sacrificado flota asimismo en los Andes "como un perenne Lázaro de luz" (10).

La rebeldía y la oposición a la conquista hispana quedan pues terminantemente expresadas encunollde dos/poemas; sin embargo la reivindicación del solo pasado prehispánico no constituye más que un episodio y la forma misma de Huaco, esta definición múltiple y exclusiva, parece ocasional. Lo esencial, y al mismo tiempo lo permanente, es la asunción de un dolor terrestre, por un momento localizado, pero que ya escapa a cualquier límite externo y presiente la universalidad del sufrimiento: "soy el coraquenque ciego/ que atado está al globo..."

Cuando Chocanc en su retórica oratoria acumula las afirmaciones precisas y decisivas, algo siempre disuena; su poesía es ante todo discurso y el sentimiento que la inspira : materia de epopeya, a desarrollarse en forma descriptiva su nostalgia, por más íntima que sea, se nutre de imágenes históricas externas, grandes hazañas, gloria, boato, pampa; su "nostalgia imperial" descansa en una visión de lujo y lujuria

(xо) La expresión "volutas de clarín", típicamente modernista, introduce igualmente una resonancia cultural en la estrofa: "Yo soy el llama ....". 
que brota del pasado ("Mi verdadero presente es el pasado") : la majestad del Inca, esplendente de sol en el trono dinástico, se confunde con la del virrey con sus vestiduras resplandecientes de pedrerías. Si el poeta llama a una de sus obras: La Tristeza del Inca, es para narrar una simple anécdota amorosa, una leyenda olvidada, (11) y si dedica una composición - ¿Quién sabe? - al indio de nuestro tiempo, lo hace aún de un modo retórico, y a pesar de la conclusión de la última estrofa (pues no siempre bastan las afirmaciones), lo hace desde fuera: el vate interroga $y$ el indio contesta con el famoso estribillo que Antonic de Ulloa y Concolorcorvo advertían ya en el siglo XVIII y que para Ventura García Calderón, en pleno siglo XX, sigue dando al diálogo con el indígena andino su carácter tan "irritante y doloroso" (12).

En la poesía de Vallejo, a diferencia de la de Chocano, no encontramos ninguna reflexión, ninguna separación, sea en el tiempo, sea en la distancia; en Huaco la utilización del simbolismo de los animales sagrados, a pesar de-su carácter inmediato y de su perfecta adecuación, traduce solamente el aspecto exterior de la verdadera y genuina expresión del poeta: ddemús el elemento reivindicativo importa menos que la sensación latente de abandono que corroe interiormente la afirmación. En el segundo terceto del soneto 2 de Nostalgias Imperiales se deja oír una queja que náufraga y al final del soneto 3 se prolonga un gemido; 10 más singnificativo de los sonetos tcdos, es su atmósfera especiap " cansancio... . derrota..." - que no procede de las influencias que hemos indicado en la técnica y la construcción de los mismos, y tampoco surge de la meditación histórica (a pesar de la aparente relación entre ambas cosas: "En el muro, de pié, pienso en las leyes..."), sino que nace de una sensibilidad propia que empieza a asomar.

Aquí cabría recordar lo que alguna vez Mariátegui percibiera sin expresarlo plenamente: "Vallejo es nostalgioso (sic) pero no meramente retrospectivo... Su nostalgia es una protesta. sentimental o una protesta metafísica...". La nostalgia de Vallejo no está vinculada con el boato de un pasado perdido y añorado y, de las estrofas de Nostal-

I(x) Está casi de más recordar que la América prehispánica apareció primero en poesía como descripción arqueológica y relato legendario : cf. el pocma de Darío: Tutecolzimi, en el cual la evocación legendaria surge de la visión arqueológica.

(12) Ventura García Calderón: Nosotros. 
gias Imperiales, a pesar de imágenes del tipo: "Reyes que por muertos dominios van llorando", se desprende ya una nostalgia mucho más profunda, no tanto la "protesta" que en ellas ve Mariátegui, como la experiencia de un desamparo que escapa a cualquiera explicación histórica (13) : es igualmente en los ojos huérfanos del poeta donde "se pudren (14) sueños que no tienen cuando". En este último verso, vemos asomar el sentimiento del tiempo propio de Vallejo, sentimiento que, según indicaremos más adelante, nunca logra intelectualizarse, inseparable de un presente mortalmente herido en su esencia misma, de un presente en que la nostalgia adquiere todos los caracteres de una angustia sin sello ni recurso en el pensamiento.

Oración del camino (p. 47), poema en el cual las imágenes siguen siendo modernistas, se inicia por un verso brusca y definitivamente marcado de ese signo ya fuertemente personal: "Ni sé para quién es ésta amargura....". No pocos de los rasgos que volvemos a encontrar aceptados y desarrollados en la poesía más original de Vallejo aparecen también en los poemas vecinos: en Hojas de Ebano (15) (p. 44.), la sensación elemental, sensación de la lluvia absurda e incesante (llueve mucho en los poemas de Vallejo, aún cuando tienen a Lima como escenario) podría presentarse como una mera notación impresionista, pero el propósito del poeta es distinto y la elección que hace de la lluvia estrechamente relacionada con la pena obscura, igualmente absurda e incesante ("Ilueve... Mlueve..."), (16) y la introduc"Jorge Puccinelli Converso"

(13) Vallejo no insiste en las imágenes espléndidas del pasado prehispánico, como lo haría Chocano, sino que se complace en acumular las palabras de la tristeza y la derrota, y a "los trovadores incaicos en derrota" del soneto 2 corresponde, en versos ya más desligados de la experiencia histórica precisa, "el alma exhausta de un poeta, arredrada en un gesto de derrota" que aparece en el soneto 4.

(14) Ese verbo intencional y creador de una atmósfera especial reaparece al final de Oración del Camino, donde confiere una tonalidad propia a una imagen que procede de Rubén Dario: "... la aurifera canción de la alondra que se pudre en mi corazón".

(15) La influencia de Herrera sigue manifestándose en ese poema, por ejemplo en la espiritualización de las puertas y sus ojeras (cf. igualmente Eguren: "como muertas pupilas son sus ventanas...") o en la asociación de vocablos "la abuela amargura", en donde uno de los sustantivos se transforma en calificativo del otro. cf. Herrera : "la abuela paz" "el abuelo silencio" ( la asociación de "una dormida novia perla" de mismo origen tiene sin embargo una resonancia ya más original).

(16) Es de advertir que éste verso no existe en la primera versión del poema, la publicada en rgr 6 en Balnearios. 
ción de una ternura familiar ("aún la veo envueltita en su reboso... (17)") y el abandono de toda preocupación de índole exclusivamente estética están subordinados a ese mismo clima poético en el cual sobrevive únicamente la raíz humilde y dolorosa de cualquier existencia, -el instinto de vida, siempre frustrado pero anterior al pensamiento: "Hay ciertas ganas lindas de almarzar y beber del arroyo y chivatear", leemos en Mayo (18) (aquellas "ganas" que parecen existir de por sí, en cierta forma despersonalizadas y dotadas de vida independiente). La conciencia desde entonces se reduce a la percepción obscura de la vida, la cual en ningún momento se afirma o afianza.

La raza nos presenta como una noción conceptual, que sería al mismo tiempo noción de combate y polémica. En "Oración del Camino" (p. 47) es personificada bajo la figura de una pobre vieja que se las" tima el propio rostro "al saber que eres huésped y que te odian"; la duda mantenida en cuanto a esta segunda persona ("eres, te odian") y a la situación verdadera del poema amplian considerablemente el personaje alegórico: todavía indecisa, se va perfilando la raza humana - sin mayor distinción - herida en cada una de sus figuras privadas de hogar propio y todas igualmente anunciadas por el "eres huésped $y$ te odian" (19).

Por lo demás las invocaciones a la raza desaparecen no bien el dolor primario y fundamental empieza a expresarse sin ningún ropaje estético. Las pocas referencias expresas a la raza pertenecen a una etapa de la elabcracióng poética en la que Mal'voz del poeta no se ha depurado aún completamente de elementos extraños; en cambio fragmentos como "ni sé para quién..." o "hay unas ganas lindas..." inician una etapa menos voluntaria $y$ por tanto más auténtica; falta todavía que el aporte cultural y el bagaje intelectual dejen por com-

(17) La pronunciación americana explica fácilmente la ortografía "reboso". Desde la época de Los Heraldos Negros, Vallejo, libre de preocupación purista, al mismo tiempo que introduce giros locales en sus poemas, no vacila en tomar algunas libertades con la ortografía oficial, en el presente caso para imitar el acento de la persona que habla.

(18) Otro verso de Mayo (poema por lo demás bastante pobre) cobra cierta resonancia profética para quienes conocen la obra posterior del poeta: "iOlı cruzada fecunda del andrajo!".

(19) El arriero peruano, "fabulosamente vidriado de sudor", a cuya pena es dedicado el poema Los arrieros, sirve también' de motivo para la meditación dolorosa del poeta : "desde un siglo de duda" y de impotencia espiritual, meditación que la transposición final del paisaje en la eternidad intenta expresar objetivamente. 
pleto de ser un abstáculo para la emoción íntima; cuando eso se haya logrado el "yo no sé..." de Vallejo, por más que siga incluyendo el eco del "¿quién sabe?" de Chocano o del "así será" de Concolorcorvo, rebasará culaquier posible lacalización; procedente de un hombre particular $y$ por ccnsiguiente insustituible corresponde $\alpha$ todo aquello que, en cualquier hombre, conserva el secreto del terror, la impotencia y simultáneamente la dignidad de la infancia huérfana y oculta; en la medida en que las circunstancias, en primer lugar geográficas, hacen de ello la condición de un pueblo entero (cabe hablar de un pueblo más que de una raza, el pueblo de la sierra y los valles interandinos, no pocas veces exilado en la costa) podemos hablar de expresión de una "estirpe", pero siempre conservemos la reserva susodicha. Solamente los paemas en donde haya dejado de manifestarse la intención de utilizar la materia ambiental ( y por consiguiente cualquier propósito reivindicador) se realizará plenamente una experiencia que las condiciones locales, si bien la facilitan, no son suficientes para explicar.

\section{IV.- INTUICION Y EXPRESION DEL AMOR}

El último poema de la sección Nostalgias Imperiales es un poema de amor : Idilio Muerto (p. 52). El título que repite las dos últimas palabras del poerna anterioreAldeana evoca un título de Herrera y Reissig: Idilio Espectral, pero el poema se organiza según un ritmo deliberadamente personal.

El verso: "ahora que me asfixia Bizancio..." (en Mayo, Vallejo había creado el verbo "bizantinar" para traducir una idea semejante), con la figura que encierra (Bizancio representa los extremos de la civilización, la ciudad en general y en el presente caso Lima, opuesta a la visión andina de la niñez), está emparentado con el simbolismo modernista, de donde procede igualmente la imagen de "la sangre, como flojo coñac" (cf. Herrera: "mis venas... ríos de vino", etc.), mientras que la tonalidad especial introducida por "dormita... flojo. ..." es algo ya característico de Vallejo. Por lo demás, a pesar del impresionismo de los detalles y de la significación inmediata de las estrofas (1), la manera de éste seudosoneto escapa a las influencias;

(r) La única imágen "transcendente" es la del $6^{\circ}$ verso. 
las palabras nobles, los vocablos dotados por los simbolistas de un valor poético propio son abandonados y substituídos por expresiones familiares del lenguaje cotidiano, perfectamente localizado ("Qué será de su falda de franela..." (2).

El sentimiento del tiempo particular, que antes señalamos como propio del poeta de Santiago de Chuco, se revela de lleno en el mismo poema, y la nostalgia amorosa sirve ante todo para liberar dicho sentimiento: conviene recordar aqui lo que Antonio Machado escribia de la poesía: "palabra en el tiempo", cuyo ejemplo buscaba en las coplas de Jorge Manrique; pues bien el nombre de Manrique nos vuelve involuntariamente a la memoria cuando leemos el primer terceto de. Idilio muerto, pero inmediatamente vemos que la intuición y experiencia directa del tiempo cobran en Vallejo una modalidad personal : lo esencial es la palabra "ahora", repetida en una posición central, idéntica en cada uno de los cuartetos; el poema nace de una sensación presente, que al principio se expresa aún con cierto alarde metafórico, pero que aparece desprovista de todo ropaje literario en la segunda estrofa: "en esta lluvia que me quita las ganas de vivir", -sensación de la lluvia, abusiva, y contra la cual nada puede hacer ese instinto primitivo que constituye la esencia misma de la vida. El recuerdo, recuerdo de una muchacha jovencita (¿pasión de niño o primer amor de adolescente?) (3), surge entonces de aquella congcija del presente; el pasado se superpone al presente que llevaba como porvenir: "sus manos... que planchaban. l.blancuras porevenir".

La distancia y la ausencia ofrecen asimismo al deseo una visión presente del ser ausente, visión que recibe de la memoria sus elementos, los cuales adquieren de inmediato cierta persistencia en la catualidad. El futurc hipotético, utilizado en las 3 primeras estrofas : "qué estará... donde estarán... qué será..." no traduce la añoranza de un pasado perdido sino que representa una privación actual, sentida - mejor dicho padecida, a través de la intuición de unas imágenes que no buscan sino reproducirse.

El último terceto indica entonces un progreso en la recuperación del pasado, perseguida por el enamorado nostálgico; las imágenes

(2) "Qué estará haciundo esta hara. . ." es un giro de la conversación familiar. En cuanto a la "tez de capulí" de la mujer amada, tantas veces celebrado en la poesía popular, cobra en ese poema la dignidad literaria que le faltaba.

(3) A pesar de existir una dama santiaguina que pretende ser la Rita del poema no hemos podido precisar quién fué la mujer evocada en csa composición. 
evocadas, en su omnipotencia, llevan al poeta a que encuentre dentro de sí mismo la respuesta a la interrogación que se ha planteado, -una respuesta que él no concluye a partir de un razonamiento sobreentendido sino que la recoge en una especie de percepción segunda que borra la percepción inmediata o la enriquece de todo lo que le hace falta: "Ha de estarse a la puerta,..." etc. La forma "ha de..." sin embargo sigue siendo fundamentalmente dubitativa, pero el "dirá, ..." que viene después, accmpañando al adverbio "por fin", afirma con una inesperada precisión.

Dicha operación está facilitada por la existencia especial de una pequeña ciudad, existencia a base de hábitos indefinidamente repetidos y en la cual lo que ayer se hizo, mañana también sa ha de hacer. La distancia se destruye por la persecución intuitiva del pasado en el presente que carece dolorosamente de él; la "nostalgia de ausencia", señalada por Mariátegui en el poema que examinamos, es el signo de una experiencios más profunda del tiempo que pronto veremos reaparecer en más de una oportunidad.

En su libro La poesía de Rubén Darío, Pedro Salinas, quien había salido a descubrir el tema vital "que desde los adentros precede misteriosamente los otros temas, Ios literarios", llegaba a la conclusión de que este tema principap estaba constituído, en el caso de Darío, por "el afán erótico del hombre": como origen de la angustia de los Nocturnos encontramos siempre "el sentimiento agónica del erotismo". A pesar de que Vallejo reconocía en Darío los acentos de una voz fraternal, el tema que sostiene su propia poesía difiere por completo del que alimenta los libros de su maestro y predecesor; en Vallejo la forma particular con la que se presenta el erotismo está al contrario subordinada a un sentimiento vital que acabamos de ver asomar por vez primera en el poema anterior. Sin embargo, en Los Heraldos Negros, más de la tercera parte de los poemas son de inspiración amorosa, y esa inspiración se somete a solicitaciones contradictorias que nos permitirán precisar la deuda de Vallejo a la poesía de su tiempa y los rasgos inéditos que lo distinguen y acreditan como poeta original.

Existe una expresión típicamente modemista de la poesía amorosa que los poetas aceptan desde las Prosas Profanas de Darío y que Herrera y Reissig ha renovado parcialmente en sus Parques Abando- 
nados o sus Clepsidras, la cual oscila entro la sensualidad pagana, el refinamiento dieciochescc y cierto idealismo de origen' cristiano. Nochebuena (p. 25) de Vallejo viene a ser, dentro de los límites del género un poema acertado (4): Las dos primeras estrofas bañan en un ambiente de fiesta galante y la emoción, puramente estética, está sugerida por el vocabulario inconfundible de la época ("quimeras de luna..., pálidos celajes.... arias olvidadas..."); versos como los primeros de éste poema inspiraron seguramente a Parra del Riego el adjetivo "preciosista" que de paso por Trujillo en 1916 aplicó al poeta todavía desconocido: "espero que ría la luz de tu vuelta... cantará la fiesta en oro mayor..." (en cuanto a la unión de la luz y el sonido, véase por ejemplo Darío: "Aúreo sonido... sol sonoro...", etc.); el título "Nochebuena", lo mismo que algunas imágenes: "la epifanía... de tu forma", y el conjunto del segundo terceto reclizan esa confusión del elemento sensual y del elemento religioso, esa traducción especial del erotismo en términos de mística, que ya practicara R. Dario y que Herrera utilizdra con evidente predilección, dando inclusive $a$ uno de sus poemas un título que resume admircrblemente la tendencia señalada: Liturgia Erótica; otro de los títules de Herrera : Belén de Amor es evocado en el último verso de Nochebuena.

El nombre de Belén vuelve igualmente en el último verso del poema Comunión (p. 22): "un domingo de ramos que entré al mundo. ya lejos para siempre, detBelén" dref. el tinals del Soneto Pascual do Dario: "Y yó... „aminando hacia Egipte Ahora bien en Comunión la evocación, en forma de letanía de la mujer amada establece como una adoración mística ("Linda Regia... Tus brazos dan la sed de lo infinito...") que recibe tambión sus metáforas de la poesía modernista, (5) pera el exceso de imágenes, no

(4) En "Deshojarión Sagrada" (p. 22), cuyo tema poi lo demás no es directamente amoroso, todos los elementos resultan asimismo modernistas (el motivo central : luna, símbolo del corazón enfermo; las palabras: "testa, gualdo, ópalo, holocausto"; las imágenes: "la testa que se deshoja" procede de Herrera (Brlén de Amor), la norlie "copa Ilena de vino" de Dario (por ejemplo Versos de Otoño), la luna que boga en la copa de la noche de Lagones (véase en L. Monguió, obra cit, p. 49) : el desarrollo. general del poema - el conjunto- es con todo bastante alambicado. El verso "frigicamente dulce de esmeraldas", que destaca por la asociación de las palabras subrayadas tiene antecedentes tanto en Herrera como en Eguren.

(5). "Tu cabello es la hilacha de una mitra de ensueño que perdi" surge probablemente de la memoria del poeta quién de niño soñaba con el obispo que algún dia sería; pero el sueña no es original, cf. Darío: "También fingia ser obispo y bendecfa" (Triptico a Nicaragua). 
siempre del todo coherentes, nos permite adivinar $\alpha$ un artista incomodado por la herencia literaria, quién busca una expresión propia a través de una forma aún tradicional que empieza por maltratar (6).

Impía (p. 37) recurre al simbolismo evangélico. Ascuas (p. 25) ofrece una representación trágica del amor igualmente regida por normas del momento cultural en que fué escrita: la "cruz que en la hora final será la luz" proviene del Responso a Verlaine de Darío; el "sol funeral", los "lúgubres vinos", la "testa" comparada a una hostia ensangrentada, la mezcla del goce $\mathrm{y}$ el horror en el acta homicida, el brebaje de sangre envenenada que depara el cáliz de una flor, el frenesí de imágenes, en una palabra el ambiente de profanación amorosa se relacionan, por intermedio de un Herrera y Reissig violento y scmbrío, con una tradición que emana de Baudelaire, autor de " $A$ une madone" o de "A celle qui est trop gaie".

Amor Prohibido (p. 61), siempre dentro de la misma atmósfera, marca un mamento diferente: después de la blasfemia, el arrepentimiento, tal como existe en Darío; las imágenes tampoco están exentas de influencias; sin embargo por el tono humilde y familiar, aquello del "can herido que busca el refugio de blancas aceras" sugiere desde el principio una resonancia personal, acentuada luego no tanto par el sentimiento del pecado, como por ese oscuro dolor ante un destino inexplicable que de pronto se intensifica gracias a la ruptura sintáctica de la última estrofa : Y saber que... etc." (7). Al mismo tiempo que utiliza medios expresivos $q$ modalidades sentimentales que no son propios, Vallejo lanza en esa forma una nota más genuina.

En Capitulación (p. 60), la repetición de "anoche" en medio de la $2^{\alpha}$ estrofa, y sobre todo, en la estrofa siguiente, la aparición tres veces en un mismo verso de la palabra "pobre" confieren a la composición una unidad emotiva particular. Esta misma unidad existe en El poeta a su amada (p. 35), donde la imagen al comienza del poe-

(6) El verso "que eternamente llegan de mi ayer" ts al mismo tiempo un acierto "preciosista" y un verso ya característico de Vallejo, quién va a utilizar en forma cada vez más libre los elementos temporales; en Encaje de fiebre encontramos igualmente "un nido azul de alondras que mueren al nacer" (reconocemos de paso las "alondras" tradicionales del simbolismo modernista que vuelven a aparecer en otros poemas de Los Heraldos Negros como Nervazón de angustia; las "heráldicas alondras" de Vallejo recuerdan por lo demás "las heráldicas cigüeñas" de Herrera en Eres todo!....).

(7) 'Tenemos aquí como el recuerdo, pera de tono menos general, del poema de Darío: Lo Fatal. 
ma que tanto desconcertara a Clemente Palma, (8) se origina en algunas expresiones de Herrera (" cruz me deparan tus brazos" -Desolación absurda; "crucifícame en tus brazos" -Ciles alucinada); lo mismo sucede con la misa amorosa de la $2^{\text {s }}$ estrofa: "se ha oficiado ... el más humano beso..." (ct. Herrera: "mi beso al consagrar sobre tus ojos" - La fuga): mientras que el ambiente general ostenta mayar criginalidad; la vuelta de ciertas palabras, el empleo de un diminutivo al final del último verso, que es también un eco del primer verso del primer terceto, ("los dos nos dormiremos como dos hermani$\left(\mathrm{cs}^{\prime \prime}\right)$ contribuyen a que esta nueva "muerte de los amantes" (9), en la cual la muerte por una vez es aceptada como un descanso, adquiera una calidad de ingenua ternura y secreta congoja que vamos ya reconeciendo de un poema a otro.

Nervazón de angustia (p. 23) (la palabra "nervazón" se encuentra en Herrerc: "una loca nervazón divina" $-E I$ suspiro), antes de las anotaciones impresionistas de la $2^{a}$ parte y la brusca terminación en una atmósfera todavía herrenianal, desarrolla sus imágenes (se pueden advertir coincidencias con Melancolía de Dario) en una forma insistente, recargada, barroca (10) y en el verso: "Desclava mis clavos..." introduce una invocación a la amante idealizada ("amada eterna") que asimila esta última a-la madre toda la vida añorada: "Oh nueva madre mía...". La aparición de la madre es significativa: en Trilce el amorbe manifesfará ante todo Como una realidad elemental que trata déosubstituircla derinuran perdida del hogar.

Los poemas de inspiración amorosa en los Heraldos Negros llevan desde ahora el signo de un sufrimiento auténticamente Vallejiano, el cual recurre todvía para expresarse a los diversos medios proporcionados por la herencia compleja del modernismo, pero al mis-

(8) Variedades -22 de setiembre de $9_{917}$ (reproducido en $\mathrm{mi}$ articulo citado de Mar del Sur, No 8).

(9) En Ausente ( $p .27$ ) descubrimos igualmente un tema muchas veces celebrado: el del remordimiento tardio (Baudelaire lo convittió en "remordimiento póstumo") de no haber amado cuando era tiempo de hacerlo; las metáforas son de tipn herreriano, tanto: "se habrá hecho de neche en tus miradas" (Herrera: "se durmió la tarde en tus ojeras", -La fuga) como "una jauria de remordimientos" (IIerrera habla de "jauria de celos").

(ra) Semejante recargo batroco, ○ acumulación de imágenes gue en greneral no son nucvas y además aceptan cierta incoherencia, es caracteristico de no pocos poemas primitivos de Vallejo on los cuales indica un esfuerzo inicial hacia la libertad de expresión, cf. más arriba el poema Comunión. 
mo tiempo intenta superar dicha herencia o utilizarla para fines prapios. El poema i...? (p. 34) (11) es un poema impresionista compuesto con elemenios de conversación como en Juan Ramón Jiménez. Bordas de Hielo (p. 24) asocia el mismo impresionismo con una prolongada metáfora (asimilación de un barco y de la mujer amada) que no presenta ningún elemento nuevo. Pero en Medialuz (p. 26), en medio de un sueño erótico con semejanzas con el anterior, reaparece la obsesión de la madre y del tiempo (" he soñado una madre... alguna madre y sus quince años dando el seno a una hora...") y la repetición: "he soñacio... he soñado..." reitera un procedimiento de traducción sentimental que Vallejo utilizará nuevamente en Romería (p. 31) ("pasamos juntos... pasamos juntos, muy juntos"). En este último poema, al lado de elementos que proceden de influencias distintas (el sueño que "lame" recuerda el "preciosismo" de Herrera y Reissig; cf.: la piedad que lame - El cura-; la penúltima estrofa proviene del Herrera obscuro y metafísico; los 2 últimos versos al contrario se parecen a versos de J. R. Jiménez), se observan otros elementos que son propiamente personales (el golpe que cae "yo no sé donde" conuncia una de esas rupturas familiares de la elocución que volvemos a encontrar, por ejemplo en Lluvia: "un dolor qué mortífero").

El simbolismo marítimo de Bordas de Hielo y Medialuz aparece de nuevo en Yeso (p.4I), entre otras notaciones e imágenes que a un cultor ortodoxo del modernismo no siempre $9 \mathrm{e}$ parecerían perfectamente conectadas y organizadas. El amor casi nunca se nos presenta feliz o triunfante en la poesía de Vallejo (Amor Prohibido, Idilio Muerto, etc.): en el poema aludido, es la muerte de un amor la que es evocada: la especie de recuperación final, aunque siempre dolorosa, en un futuro indeterminado, de una feminidad trascendente ("Y ha de vibrar el femenino en mi alma, / como en una enlutada catedral") parece que tiene tan sólo una significación momentánea: la idealización, la trascendencia, cuando asoman en la poesía de Vallejo, derivan más de la cultura que de la personalidad profunda del poeta, con lo cual no quiero decir que semejantes tentativas de transposición resulten insinceras, sino que son el producto de una elaboración intelectual, algo consciente o voluntaria y directamente relacio-

(i1) Una poesia amorosa de Panoplia Lirica tiene igualmente como titulo un simple signo de interrogación. 
nada con el ambiente espiritual y el medio culiural de la época (12): la emoción se viste aún de disfraces literarios.

De todas maneras, el sentimiento de frustración infinita que se insinúa en el amor domina en el poema Para el alma imposible de mi amada" (p. 63) ( el Abel Martín de Machado establecerá coma principio: "la amada es imposible"), en donde la mujer es llevada a un lugar ideal e incarpórea. "en la eterna nebulosa... en la multicencia de un dulce noser", mientras que el amante sigue víctima de la carno pecadora que está fustigando (13). En Amor (p. 69) la remuneraclón a la came (que en vez de zanjar las distancias las exagera) se ha realizado: "Amor ven sin carne...". y el amor es un amor celeste, transfigurado, lustral, el mismo que constituye un indicio de salvación en Visión de Rubén Darío (14). Pero esta nueva referencia a Darío (15) basta para establecer un parentesco literario que sitúa una vez más la compasición de Vallejo en el ambiente de una época.

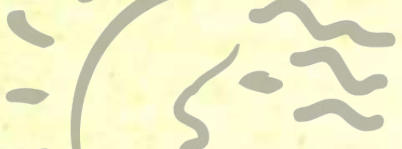

Paralelamente, en El tálamo eterno (p. 63), el fracaso continuo de la vida en la iluscria posesión amorosa (las imágenes dedicadas a traducirla encierran intencionalmente un elemento grotesco) con-

\section{Biblioteca de Letras}

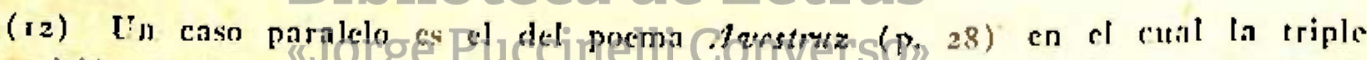
superposición de la melancolia, al avestrü (réplica sin gracin del cisne modernista) y la mujer se organiza según influencias múltiples (el Baudelaire do los Splects, seguido por el Herrera y Reissig de la Desolación absurda, etc.); en. e] cletalle, los 'trigos de luz' se cmparentan con Darío (La espiga), mientras que cicrtos giros familiarcs inesperados ("melancolía, basta!") o algunas asociaciones de vocablos ("Melancolía... tu dulce pico") anuncian la nota personal. Mongutió -p. 50- relaciona ta "gran 0 de burla" del ataud con un verso de tugones en los furgos artificiales; una imagen de idéntico indole nos ofrece Herrera en el final de Desolación absurda: "yo te abriré con mis brazos un paréntesis de amor".

(13) ........... la carne que se vuelve una ohsesión en La copa netgra (p. 38), pocma en donde la acumulación clo imágenes sin mayor originalidad es apenas compensada por el carácter aficbrado del conjunto: "Ah, mujer! Por ti existe la carne hccha instinto. Ah, mujer!" (recenocemos en esta invocacion como el eco, menos sereno, de la exaltación de Dario en el poema "Carne, celeste carne. .").

(if) Es de notar el vocabulario modernista del poema de Valejo, especialmente la palabra "icor" (que encontramos on un poema igualmente "inmaterial" do Da. rio El poeta pregunta for Stella) y casi simultáneamente el uso de un vocablo familiar, para un peruano sobre todo, como "rifado".

(15) Cf. el libro ya citado de Salinas: La poesio de Rubén Dario, 
duce a una afirmación de la muerte como única reconciliación pasible "en una cita universal de amor" (16). Sin embargo, las expresiones: "dulce es la tumba... dulce es la sombra..." llevan, a pesar de su abolengo romántico, una cualidad decididamente original; $y$ el verso: "una vida de vida agonizante" pertenece por completo $\alpha$ Vallejo, quien empieza a utilizar, para traducir aquella experiencia de la destrucción temporal que le es propia, todos los recursos de las palabras que dicen la vida y la muerte. La vida, desde ese momento, es sentida como agonía.

En adelante los poemas, renunciando a toda trascendencia, se limitarón a dar cuenta la más exacta posible no tanto de la alegría o la tristeza, sino de algo todavía más inmediato, el bienestar, la incomodidad, la angustic, estados primitivos todos, cuya traducción nunca puede ser más que fragmentaria. Los puntos suspensivos, las rupturas constantes del ritmo nos ofrecen entonces el equivalente gráfico de esta elaboración elemental. En Setiembre (p. 36), el amor sigue acudiendo a símbolos e imágenes talvéz no universalmente admitidos, pero lo importante no son los símbalos e imágenes sino la afirmación de estados contradictorios -aceptados sin ser entendidos, e igualmente la insistencia en la afirmación, ya que el dolor difícilmente podría ser elucidado o eludido: "Yo no sé lo demás... yo no sé por que fuí triste...", y un poco antes: "no debiste ser buena, no debiste".

La incomodidad y la angustia resultan efectivamente mucho más constantes que el bienestar, el cual cuandd apapece siempre va mezclado de un obscuro sentimiento de culpabilidad: "Yo no debo estar tan bien...", leemos por ejemplo en EI palco estrecho (p. 32), especie de monólogo transcrito directamènte (cf. más tarde Trilce, 51) y dirigido a una compañera muda: un palco (?) de teatro que es también un barco, -la lluvia que nace no se sabe donde pero que aparece nuevamente como el signo de los límites, de las amenazas exterioresuna tierna humildad que es a su vez el signo del único infinito al cual podamos acercarnos: "Más acá, más acá...", "avanza, avanza el pie

(a6) En Fresco (p. 40) la ternura pasada de un antigto idilio amotoso (con los colores campesinos que hemos visto en Idilio Mucrio) se salva al contrario, gracias a la ternura permanente (un cariño que no nace nunca, que nunca muere") de la naturaleza personalizada y como divinizada de acuerdo con un panteísmo simbolista propio de la época (cf. A. Orrego). 
...". A pesar de los versos intermedios (en los cucles encontramos imágenes de cuño modernista: "una nave cargada de crespón", un "aplauso" comparado a "un festín de rosas negras", etc.) la forma do expresión es muy diferente de aquella del poema Desnudo en Barro (p. 59), entre otros, donde la amenaza que agobia la vida cotidiana termina en un verso que recuerda la conclusión de El tálamo eterno: "La tumba es todavía un sexo de mujer que atrae al hombre!".

En cambio un poema como Lluvia (p.69) presenta íntimo parentesco de expresión con El palco estrecho, logrando traducir inclusive algo más primigenio y elemental: la sensación exterior (la de la lluvia siempre) y la realidad interior (el dolor) están íntimamente confundidos, y si bien en la $3^{a}$ estrofa reaparecen metáforas de tipo modernista, mueren luego al irrumpir de nuevo la sensación con su monótona insistencia: "Mas cae, cae el aguacero....".

En Heces (p. 37) se unen iguaimente la anterior peculiaridad emotiva de Vallejo con supervivencias literarias en la expresión del amor: "Esta tarde llueve como nunca: y no tengo ganas de vivir corazón". La "tarde", la "lluvia" (esa lluvia de Lima que nunca lo alivia a uno, sino que al contrario debilita lentamente el instinto de vida y lo va poco a poco consumiendo). - - sa sempiterna monotonía que no excluye a veces cierta dulzura paciente y pasiva: "esta tarde es dulce... viste gracia y pena. . iyjste de mujer instala en el interior de la sensación ("Y yo recuerdo") y las dos estrofas que siguen, "derformal bastante confusa y llenas de influencias, expresión directa vuelve a surgir repentinamente con el verso: "Por eso esta tarde...". El giro lógico aquí incluído no tiene por supuesto ningún significado propiamente lógico: en el curso del poema indica simplemente que la sensación se impone otra vez, valiéndose todavía de uno que otro elemento que el poeta recibe de sus lecturas, (17) antes de abandonar todo ropaje literario y reaparecer finalmente en su obsesionante desnudez que no acepta la menor elaboración metafórica: los dos últimos versos reproducen los dos primeros acentuándolos tan sólo mediante una nueva puntuación.

(17) El buho, simbolo del corazón nocturno, es el ave de Dario, después de abanmi hondo dolor" consciente o inconscientementeso, y el verso: "en la abrupta arruga de so de Herrera y Reissig: "la arruga de mi mal transpone en forma casi literal un ver- 
El verano volverá -Verano (p. 35)- pero el apóstrofe del poeta : "Verano, ya me voy..." redobla en el presente con fúnebre resonancia; la muerte (una vez más relacionada con el amor) no es considerada por Vallejo en la distancia del futuro, sino que viene a constituir el ambiente mismo de la vida, el medio circundante del cual no es pasible escaparse; todos los días son días de sepulcro: "Todo ha de ser ya tarde..."; uno presiente que no existe salida alguna y la consolación que termina el poema: "Ya no llores, Verano!..." resulta agregada (18) un tanto artificialmente.

En esa experiencia inmediata del tiempo que "se come la vida" (Baudelaire), la trascendecia a veces vuelve a introducirse pero nunca hasta el punto de cuajarse en una forma intelectualmente elaborada. "Pureza amada, que mis ojos nunca llegaron a gozar. Pureza absurda!": Deshora (p. 39) empieza por una invocación de ese tipo que surge de una nostalgia y más aún del sentimiento de algo irremediablemente ausente : el "Yo sé..." que sigue inmediatamente después parece que fuera una réplica de todos aquellos "yo no sé" que leemos en otras composiciones, aunque de nada sirve pues el llamado a la pureza es acompañado de la negación para siempre de su presencia. Las imágenes pasteriores se aproximan a ella sin alcanzarla y el tiempo todo se reúne y resume en la privación del instante, -el tiempo del dolor y el de la alegría, el tiempo de la ninez anterior al pecado $y$ el de ahora cuando Ia fardè aailluvia $y$ la crenunciación reinan una vez más, en su persistente unidad.

El poema no avanza sino por intuiciones sucesivas y sentimentalmente vividas; después de una invacación a la pureza: "Oh pureza ..." encontramos una exhortación patética escrita en el imperativo plural y de la que uno no sabe al principio a quién va dirigida: "Alejaos de mí, buenas maldades..." (la reunión de dos palabras que lógicamente se excluyen, se volveró frecuentemente y a veces desconciertan en la poesía posterior de Vallejo; en el presente caso tiene un significado claramente relacionado con el amor), y luego una afirmación que, por encima de los dos versos que la preceden, se enlaza nuevamente con la aspiración a la pureza: "Yo la recuerdo", el pronom-

(18) El última verso utiliza nuevamentc en forma bastante personal los elementos temporales contradictorios, como ya advertimos en la nota No 6 , pero las preocupaciones formales tienen aquí todavía come en los dos casos anteriomente señalados un papel importante. 
bre "la" representa precisamente a la pureza, pero la estrofa intermedia ha servido para oponerle la realidad física del amor cotidiano y el primer verso de la estrofa última resume noslálgicamente la oposición.

Los dos versos finales son introducidos por la conjunción "pues", que está usada en forma insólita, ya que la conclusión no tiene relación lógica inmediata con lo que antecede; en realiciad es la sensación tempora! la que bruscamente se extiende y llena el horizonte entero del poema : la "tarde", que hemos visto relacionada con la muerte, es experimentada como un tiempo eterno ( ya no existe ayer ni mañana: "perenne tarde"), en el cual se realiza la agonía eterna de la vida, una vida primaria y sin protección cuando se trata de vivirla, pero que en cambio posee recursos infnitos de inuerte (el último verso ya escapa de toda preocupación formal y empieza a utilizar las opogiciones retóricas del lenguaje para traducir el sentimiento agónico intensamente sufrido, según un procedimiento que más tarde habia de encontrar campo ilimitado en Poetmas Humanos); el amor se pierde en el morir.

Ahora bien, Lineas (p. 60) invoca al contrario el triunfo del amor sobre el destino, pero no por eso volvemos a las idealizaciones cuyo origen modernista señalamos anteriormente. La técnica del poema es algo original $y$, en algunos de sus aspectos, la forma de expresión anuncia la de ciertos poemas de Trifce; Cresull a primera vista incoherente, pues pasameschePunacistaloCinicialisen dcinde tiempo y amor se enfrentan a través de unas metáforas complicadas, a una segunda estrofa con afirmaciones trascendentes, afirmaciones que se reducen a un simple anhelo en la $3^{a}$ estrofa, mientras que en la $4^{a}$ una visión en proceso de formación trata de confirmarlas, recurso supremo contra la destrucción y la duda ya sensibles en la intuición que abría el poema, el cual vacila finalmente y no puede ratificar el anhelado triunfo sobre "lo ciego y lo fatal". La impresión general es la de un llamado que a pesar de las afirmaciones centrales, no logra concretar su objeto.

Da la amenaza profunda y obscura que el tiempo no cesa nunca de renovar, lo única que puede surgir en ciertos momentos privilegiados es esta ardiente aspiración hacia la unidad que aparece en $A$ bsoluta (p. 58): "Oh unidad excelsa! Oh lo que es uno/ por todos!/ Amor contra el espacio y contra el tiempo!", pero a la invocación se adhiere inmediatamente una imagen abstracta (introducida por un " $y$ " cuya función sintáctica es ilusoria), y el llamada místico que nacía de la 
destrucción temporal con intención de redimirla se agota en esta imagen misma: "Una arruga, una sombra!". La última estrofa modifica la estructura entera del poema: después de abandonados los recursos ordinarios del lenguaje, este a su vez empieza a luchar con condiciones nuevas que serón las de Trilce, donde linderos y números aparecerán en forma permanente dotados de una vida barroca y sin coherencia objetiva para simbolizar los absurdos límites de la existencia.

Estamos lejos de un poema como Unidad (p. 71) cuyo título nos recuerda algunos versos de Absoluta: en Unidad, el poeto que incluye la materia de su experiencia propia en el cuadro rígido del soneto sigue dominando perfectamente dicha materia pcética; los dos cuartetos desenvuelven una imagen coherente inspirada de nuevo en el Herrera y Reissig tenebroso, y los dos tercetos se organizan sobre la base de una oposición retórica claramente expuesta, a pesar de que encontramos en el primer terceto una imagen cuyo acento está directamente emparentado con el tono general del primer poema: Los Heraldos $\mathrm{Ne}$ gros. Con Unidad volvemos de los extremos que habíamos alcanzado en Absoluta para encontrar nuevamente el punto de partida del presente capítulo. Nos toca ahora seguir en otra serie de poemas, en los cuales no asoma el tema amoroso, la conquista por Vallejo de la expresión auténtica de su dolor y de su existencia.

\section{"Jorge Puccinelli Converso"}

$$
\text { V.- "YO NO SE" }
$$

\section{ANGUSTIA HAMBRE Y ORFANDAD}

Una de las composiciones que hemos encontrado publicada en 1917 en Balnearios es la llamada Pagana; la versión de 1918 (p. 66 Ed. Miró), amputada de una estrofa, presenta asimismo otras modificaciones que tienden a volverla más ágil, pero el significado general no ha cambiado; la intuición particular del poema está envuelta en un simbolismo entonces de moda que sería difícil relacionar con el ambiente de la época; superación consciente de la emoción, representación trascendente de la vida, separada del sufrimiento inmediato que inflige el huir del tiempo. 
La voz del espejo (p. 54): "Ásí pasa la vida... así pasa la vida. ...etc" también corresponde, a pesar del estribillo antedicho de tonalidad diferente, a una preocupación de carácter todavía intelectual: la obscura amenaza se transforma en el "dogma del fardo matador" y. si bien la expresión "fardo matador" escapa por su prosaisismo al ambiente modernista, son metáforas tradicionales las que luego se substituyen a la palabra directa: "el manzano de la Ilusión" y la "orquesta de Esfinges" que representan la existencia se apoyan a las claras en el pasado cultural; la intervención personal, aún bastante tímida se deja tan sólo presentir en el verso; "yo voy todo azorado, adelante... adelante..."; en cuanto a la expresión "rezongando $\mathrm{mi}$ marcha funeral" es de nuevo algo literario (Baudelaire, Herrera y Reissig).

Ya sabemos que cuando Vallejo empezó a escribir sus poemas no había renunciado del todo a expresar sus ideas a través de imágenes "selectas" y cuando un amigo, pobre de cultura o perspicacia, trataba vanamente de entenderlas, el autor aceptaba a veces explicarle lo que el poema "quería decir": La araña (p. 30) "con la cabeza y el abdomen separados simboliza al hombre y el filo de la piedra a la vida ...La cabeza pugna por ir hacia arriba, hacia el ideal, en cambio el vientre hacia abajo, hacia la tierra" (1). El poeta en éste caso se inspira en una anécdota para darncis una imágen simbólica de la vida; si la personalidad propiádélallejo asomáalensel poema es más por el tono compasivo que por el símboloc y más que por el modo de desarrollar el tema pcetico, por la sugestión incluída en los tres últimos versos, ya anteriormente oídos en las estrofas que preceden (sobre todo el verso de la conclusión: "Y me ha dado qué pena esa viajera!).

En Las Piedras (p. 64), el punto de partida es igualmente una anécdota pero la piedad universal del poeta redime el poema entero de un simbolismo fácilmente explicable; cuanto puede existir en el universo de bondad y de sufrimiento es transferido a la materia espiritualizada, mientras que lo propiamente humano, lo reservado al hombre, parece reducirse a una maldad gratuita que sólo la presencia de la madre puede salvar y hacer perdonar (es de advertir por primera vez en Vallejo la expresión "Madre nuestra" como transposición del "Padre nuestro" del Evangelio); la última estrofa no termina tanto la composición como la prolonga con la inusitada insistencia en la misma palabra "piedras" : "de las piedras/ de las piedras/ de las piedras

(1) Referido por Izquierdo Rícs en su artículo Santiago y Vallejo. 
..." (cf. Líneas: "Un Bautista que aguaita, aguaita, aguaita..."); la congoja - la profunda congoja de un niño- aunque atribuída en este poema a las pobres piedras, resulta ya difícilmente superable.

La organización simbólica - como aquella que se encuentra en En las Tiendas Griegas (p. 53), de los distintos elementos del hombre en un fondo crepuscular a la Albert Samain- la organización simbólica coherente es constantemente maltratada en gran parte de los poemas por la exigencia emotiva. El "Yo no sé" que constituye la palabra inicial del libro anula o limita cualquiera tentativa prolongada de superación.

El poema Los Heraldos Negros (p. 21) es al respecto sumamente característico ya que desde el principio confiere una atmósfera precisa a la obra entera: empieza por una afirmación, la afirmación de algo que golpea y lastima y cuya violencia es enorme, pero algo también que no puede de ningún modo ser expresado o explicado: "...yo no sé..." -tenemos aquí la confesión de una incapacidad inicial que los versos que siguen intentan corregir por una serie de aproximaciones, las cuales resultan todas ineficaces; el poetc acude inmediatamente a la causa más fuerte que pueda ser invocada para tan excesivo sufrimiento: la hostilidad de todo, el odio mismo de Dios; luego aparece como segunda causa posible, no precisamente la memoria de todos los daños padecidos en el pasado, sino la irrupción súbita y como el diluvio en el presente de todo el pasado de dolor - el peso total de la vida sensible en"el instante actual.

Pero nunca Vallejo logra comprender el mal que está sufriendo; en el giro mismo de la comparación : "como de... como si..." vemos el temor de afirmar razones, o más bien una imposibilidad esencial que lleva entonces un eco del primer verso, un nuevo : "Yo no sé" repetido al final de la estrofa. La única afirmación que siempre vuelve es la afirmación de la herida, afirmación obstinada y que no se ha encontrado equivalente: "Son pocos, pero son...". La expresión pierde entonces algo de su originalidad ideal para pintar físicamente los efectos de los golpes terribles anunciados al pricipio : el paeta reinicia su investigación en pos de causas y razones pero ésta vez busca auxilio en sus recuerdos y lecturas, y el espanto va envuelto ahora en dos imágenes simbólicas, una histórica y la otra apocalíptica, de evidente arraigo cultural, aunque también marcadas como el poema toda de una incertidumbre fundamental: "Serán tal vez...".

Al pasar nuevamente de ese futuro dubitativo al presente, el poema se reduce a una nueva afirmación del abandono y la angustia en 
la hostilidad general de todo lo exterior al hombre - "el Destino" - : pero la terminología religiosa ("Cristos del alma ... fe ... blasfema ...") es menos propicia a traducir el dolor y congoja que aquella imagen familiar y aparentemente sin nigún relieve "poético" tradicional que encontramos después: "scn las crepitaciones de algún pan otc..." la obsesión del hambre y del pan que se quema y siempre le es negado a uno va relacionada desde este momento inicial con la obsesión infinita del abandono, y termina luego de una vez con toda elaboración imaginativa tradicional.

El poema no se desarrolla en forma continua o coherente. El " $Y$ " que encabeza la estrofa 4 rompe la enumeración; llamada por la penosa evocación del "pan que nos quema", surge y se.impone la imagen misma del hombre -una imagen del todo inquieta e inquietante - : el poeta. al mismo tiempo que se identifica con ese hombre, no posee en presencia suya sino una piedad inmensa absolutamente desprovista de medios y recursos: "Pobre. pobre..." y no puede más que expresar gráficamente su terror y desconcierto: "vuelve los ojos ... vuelve los ojos locos?." (los ojos, criterio de la emoción cuando la palabra resulta impotente). "Todo lo sufrido" del principio del poema viene a ser lo mismo ahora que "todo lo vivido"' y es en la locura de la mirada donde vuelve a aparecer la figura de la segunda estrofa. El último verso, aislado repite el primero; no hemos avanzado nada; el pcema terming en un inmenso fracaso conceptual; lo único que persiste es una pena ciega e ilimitada. El simbolismo interno de la composición, las imágenes no siempre nuevas ni del todo convincentes en el detalle ("zanjas oscuras", "charco de culpa") se pierden y olvidan en el eco sin respuesta del "Yo no sé".

La última composición del libro Espergesia (p. 77) ha sido relacionada por Basadre con la tradición romántica de aquel "sino doloroso" del cual el poeta declara ser víctima; por lo demás encontramos en el poema muchos elementos prestados (el humorismo trágico procede de La torre de las Esfinges de Herrera y Reissig). El arreglo del poema es sin embargo personal.

"Yo nací un día/ que Dios estuvo enfermo"; estos dos versos vuelven constantemente (estribillo nostálgico que se "agrava" al último), ora aislados. ora enlazados con la estrofa anterior por un "pues" más familiar que lógico, y se va organizando una de esas confesiones cujos ejemplos mejor logrados están en Trilce; es una confesión humilde con sus descansos y sus vueltas: "Hermano, escucha, escucha...- y 
bueno... y qué...". El par de expresiones retóricas : "Todos saben que...". "Y no saben que..." también se repite pero en forma libre y cada vez algo distinto; el saber en este caso se reduce a afirmar la existencia ("que vivo"), y la culpabilidad ("que soy malo") y las funcicnes elementales de la vida ("que mastico") (el último "todos saben"... inclusive está seguido solamente por puntos suspensivos), y de iodos lados la ignorancia del hombre va tropezándose con el misterio inquietante, no exento a veces de un matiz grotesco. La última imagen juega con una palabra abstracta: "lindes"; entonces como más tarde en Trilce se propaga en el poema la sensación intolerable de los límites.

El tiempo asimismo es individualizado (cf. Absoluta): "y no saben/ del diciembre de ese enero" (enero representa lo actualmente dado, conocido, y diciembre lo que nos espera y hacia la cual propendemos; ambas palabras aparecen nuevamente con mayor extensión un poco más abajo: "Y que no me vaya/ sin llevar diciembres/ sin dejar eneros..."). La unidad del poema surge de la combinación de todos esos elementos inconexos citados sucesivamente y que la emoción inspira y utiliza directamente; dicha emoción más individual y aparentemente menos angustiada que la que hemos señalado en el poema Los Heraldos Negros corresponde sin embargo exactamente a la del otro extremo del libro, participando en aquella fatalidad dolorosa estrechamente vinculada con la experiencia temporal, que Vallejo no deja nunca de afirmár singresolver o aceptarla.

Cundo quiere a veces elevarse por encima de ella, tenemos un poema como Los Dados Eternos (p. 66) donde la búsqueda de una expresión trascendente es inequívoca; la dedicatoria a González Prada sitúa esa composición en la tradición de un estoicismo altivo y un orgullo humano desesperado que desafía al destino de imodo que la nota verdaderamente personal se advierte tan sólo en cierta libertad de la estructura, en, el "Dios mío" de la última estrofa (la ternura del poema va también hacia el Dios que evoca, impotente e insensible), y sobre todo en los dos primeras versos del poema en los cuales la emoción no se ha revestido todavía de frases o pensamientos (cf. más abajo el poema: Ágape).

Las referencias a Dios en Los Heraldos Negros oscilan entre una rebeldía irreverente y una lástima apasionada: ambas actitudes están 
situadas en dos planos de existencia fundamentalmente diferentes, uno intelectual y pasajero, el otro profundo e intuitivo. El primero de ellos es el representado en Los Dados Eternos, y también aunque en forma ya atenuada en La de a mil (p. 56): en este último poema el punto de partida de la reflexión es un episodio callejero ( no es necesario recalcar el sínnúmero de vendedores de "suertes" que andan por las calles y las plazas de las ciudades peruanas). El simbolismo queda claramente expresado: el muchacho deshaparrado, el "dios bohemio" que vende la fortuna al azar representa al Dios "nominal" del Azar universal, el cual rige las destinos humanos. El poema termina en una pregunta que no recibe respuesta, pero en el decurso del poema la afirmación abstracta del principio está menos separada que en Los dados eternos del sentimiento inmediato, siempre idéntico: sentimiento irresistible de una hambruna, una privación universal ("entre panes tantálicos humana impotencia de amor") en la postración temporal ("en éste viernes tibio/ que anda/ a cuestas bajo el sol": el factor temporal resulta individualizado (2) y la sensación personal en esa forma transferida se vuelve aún más irreparable).

En Santoral (p. 68) vemos al poeta erguirse frente a Dios ("Viejo Osiris") en plan de oposición e igualdad ("Soy la sombra, el reverso..."); irreductible, perdona a Dios desde lo más altivo de su integridad ("Viejo Osiris! Perdónote. C.."); - es lel momento del triunfo (?) sobre la vida: "Ileguéphastânlal pared de denfrente de la vida./ $Y$ me parece que he tenido siempre/ a la mano esta pared", y entonces Vallejo, utiliza un procedimiento de repetición de temas, que ya hemos apuntado no pocas veces, para dar la sensación de un tiempo eterno ( un tiempo que escapa de las categorías ordinarias que se le atribuyen) en una fórmula vigorosamente abreviada: "así he llegado a la pared de enfrente:/ y siempre esta pared tuve a la mano..." (el "me parece que" que marcaba el pensamiento intermedio queda suprimido: el poeta llega ahí donde ha estado siempre, ahí donde nunca ha dejando de permanecer); pero semejante triunfo lleva a las claras un signo negativo: no es sino el revés mismo de la muerte.

(2) En Herrera y Reissig podemos encontrar inłágenes como "Bosteza el buen domingo, zángano de semana..." (Dominus Vobiscum), pero con caracter mucho más fragmentario, episódico y en cierta forma exterior, descriptivo, mientras que en el presente caso estamos en el centro mismo de la experiencia de Vallejo y de su traducción poética. 
La angustia que siempre domina abandona las ropajes de la antigua retórica; la actitud de desafío pretende ser estoica, "bravía y selecta" (3), mas el dolor se revela demasiado irresistible para que sea posible mantenerlo alejado: en Los Anillos Fatigados, un solo dedo se levanta todavía, acusador ("Señor;/ a tí yo te señalo con el dedo deicida...."), agotándose inmediatamente la rebelión pues el dolor es experimentado como una fatalidad general de la cual Dios tampoco se salva, ese Dios de largo suicidio monótono que pasa y pasa, sin repciso, agobiado de tiempo y universo, como el Dics cansado de Eguren.

Los anillos fatigados (p. 67) presentan precisamente una curiosa síntesis de la expresión personal de Vallejo y de las últimas referencias a una forma de expresión anterior. El poema se inicia como Los Heraldos Negros por una afirmación pero de algo más elemental todavía: "Hay ganas de..." -ya no tenemos aquí retórica alguna sino sencillamente el deseo, el deseo visceral de perpetuarse, el deseo casi impersonal de una conciencia individual atenuada (Vallejo escribe: "hay ganas " en lugar de: "tengo ganas") y contradiciendo la sensación desgarradora de distancia y lejania causada por el tiempo, nace al mismo tiempo el deseo opuesto de terminar con todo, el cansancio excesivo que destruye la substancia de la vida, es el flujo y reflujo, físicamente identificado del deseo que nunca se resuelve (para eso habría que separarse de él), sino que es narrado con ayuda de una imágen espontảngea, sincipretensión Viteraria, y en la cual el neologismo "istmarse" acentúa su violencia.

En la segunda estrofa la expresión "Hay ganas de....." va seguida de una figura ya más elaborada, menos pura. Pero, se detiene de pronto antes de formar una nueva metáfora que de todos modos resultaría débil a inadecuada; la derrota y la renunciación definitiva se consumen en la pirueta verbal que vuelve contra sí mismo las ganas elementales de vivir: "Hay ganas de... no tener ganas". Los versos que siguen dan al poema forma completa de poema pero no logran sino desarrollar, debilitándolo al mismo tiempo, éste como aborto de la expresión y la existencia; el estilo es de nuevo tradicional y la angustia trata otra vez de traducirse en forma más literaria (el verso "Cuando las sienes tocan su lúgubre tambor...", no

(3) Son los propios términos de la dedicatoria de "Los Dados Eternos" a Manuel González Prada. 
tiene moyor calidad estética y recuerda unos verses de Baudelaire, sir que por lo demás "el ansia por la nacla" del pota francés tenga nada que ver con la congoja propia de Vallejo); sólo el ú!timo verso, con la reaparición de "hay ganas de..." y la familiariclad de la expresión reproduce, al final del poema, la misma atmósfera del comienzo.

En el posma Dios (p. 70), Dios ha dejado de ser el ejemplo ciel azar; antes pensado y por lo tanto exterior, helo aquî vivido e interiorizado; se confunde con el dolor más hondo del poeta, un dolor quizás no ton radicalmente despojado como en el pcema anterior, pero igualmente definitivo ya que es experimentado como el equivalente mismo del amor. La tonalidad general parece más nostálgica y menas desgarradora que la de Los anillos fatigalos, sin embargo, representa idéntica impotencia. La expresión no está del todo liberada de influencias (hasta la formación de neologismos como "mustiar" puedo tener antecedentes en Herrera) pero la marca personal se hace patente una vez más a través de elementos que ya conocemos: carencia de desarrolo lógico y en cambio. persistencia de la afirmación que reaparece de estrofa en estrofa y que se traduce imperfectamente mediante los recursos literarios conservados (el discurso de la primere estrofa se detiene bruscaniente y el : "Siento a Dios" inicial vuelve a presentarse baja la forma "pero y i siento a Dios" - por supuesto, "pero" no tiene ningún yalor adversativo, siendo tan sólo el signo de la incapacidad para proseguirla elahoraciónadel sentimiento cuando éste vuelva a irrumpis con una fuerza alensiva superior a toda traducción.

El hecho de quai semejante experiencia se desarrolle dentro de condiciones temporcles determinadas se hace de nuevo evidente en el verso: "Oh, Dios mío, recién a tí me llego,' hoy que amo tanto en esta tarde", y si el amor ablanda el clima entristecido de la tarde, también resulta amenazado o ilusorio ("falsa balanza.... frágil Creación...") en el ambiente de "orfandad" que ya empieza a precisarse.

Tres poenas de la sección Truenos : Agape, El Pan Nuestro y La Cena Miserable (los tres títulos indican una común obsesión alimenticia) relacionan esta "orfandad" con la inexplicable desnudez de la existencia cuyo supremo testimomio se encontrará en los Poemas Humanos, veinte años más tarde. Todo lo que es noción, producto de enseñanza, resultado de algo aprendido, ha desaparecido en la posible. 
En La Cena Miserable (p. 62), de la sensación de la vida primitiva y carente de eficacia surge tan sólo una queja : "Hasta cuanda..." que se repite con terrible insistencia. El poema se inicia, se interrumpe, vuelve $\alpha$ iniciarse, y siempre aquella pregunta que no espera respuesta se impone en sus desconcertante sencillez; dentro de la manera general regida sólo por la emación, subsiste sin embargo más de una forma antigua 0 anticuada y el simbolismo del conjunto, la comparación de la vida como una cena, no es tampoco completamente original, pero, en la atmósfera propia de la composición, las palabras que tienen relación con el hambre adquieren un carácter inaudito: "ya nos hemos sentado/ mucho a la mesa....." (4); nunca hay bastante de comer, nunca hay manera de saciarse y el único deseo que logra elevarse desde semejante comprobación traduce ahora la aspiración a la unidad en forma muy distinta de la que vimos en Absoluta : "Y cuando nos veremas con los demás al borde/ de una mañana eterna desayunados todos".

Ninguna respuesta es posible y en la última estrofa (compárese : "Hay alguien que..." con "Hay golpes en la vida..." - Los Heraldos Negros - y : "Hay ganas de ..." - Los Anillos Fatigados) se advierte solamente la presencia de tado lo que amenaza y de aquel dios azar que ya no es mencionado pero que de todas maneras multiplica la fatalidad del dolor humano al presentirse que él también comparte la ignorancia bhumang ": "Y menos sabef ese oscuro...". Una presencia de ese tipo, por muy fragmentariamente elaborada que sea, deja por ello de manifestarse como irreductible a cualquier explicación; por encima de todo se extiende y establece la obscura certidumbre de una falta absoluta de justificación y de una penuria absoluta de recursos : "Hasta cuando estaremos esperando lo que/ se nos debe...".

(4) Lo que sigue: "........con la amargura de un niño/ que a media noche llora de. hamire, desvelado........", lo podemos relacionar con un rasgo personal de la niñez del poeta que me ha sido contado en Santiago, cf. mi artículo de Mar del Sur, No. 8, el cual me permito reproducir : "el muchacho solía atizar el fuego del horno donde se cocía el pan familiar, y aprovechaba para sacar panes a escondidas, que ocultaba bajo su álmohada para comérselos de noche; cuando lo sorprendieron en sus banquetes nocturnos, declaró a sus padres : «Estoy soñando que estoy comiendo el pan que hemos amasado hoy» También al trazar garabatos en el suelo, sin saber escribir todavía, afirmaba el niño : «Estoy escribiendo a mamita que tengo hambre». De la constante obsesión que desdo entonces tuviera de una posible hambruna, tenemos por lo demás el testimonio del mismo Vallejo en el cuento de Escalas Melografiadas que se titula Alféizar y relata una anécdota de los años santiaguinos. 
El principio de El Pan Nuestro (p. 57) parece anunciar un poema de indole impresionista o intimista (par otra parte la imagen : "La mordaz cruzada de una ccrrera, etc...." pertenece siempre a la manera de Los Extasis de la Montáña) pero, a pesar de las apariencias, desde la primera línea resulta prepondercunte la intuición sentimental. "Se bebe el desayuno....." : la congoja y el abandono esenciales estón contenidos en la sensación del beber y el comer que se extiende al universo entero (las carretas arrastran "una emoción de ayuno encadenado") y la ternura adolorida del poeta (ternura y dolor sin consuelo ni motivo determinado), que repite el mismo anhelo de $L a$ Cena Miserable, se substituye directamente a la evocación exterior y a sus componentes literarios (5) ("se quisiera...": comienzo de estrafa que volverá a aparecer con variantes en poemas Humanos). La invocación del Padre Nuestra que corona el movimiento señala una pausa, al mismo tiempo que justifica el título del poema.

El principio de la estrofa siguiente indica un nuevo arranquo rítmico que corresponde a una fóse nueva de una lógica emocional tan exigente como inexplicable. En la poesía de Vallejo, secjín ya advertimos, la emoción inmediata aparece muchas veces en forma tan primigenia $\mathrm{y}$ elemental que sólo encuentra una traclucción literalmente impersonal (cf. p. ej. la fórmula: "Hay ganas de ..." en los Anillos Fatigados, en la que "las ganas" vienen a existir fuera de todo apoyo personal), Yy lcuandet de depente astistimos, como ahora al despertar a los primeros glbores ide la conciencig personal, ésta última no contiene más que el sentimiento opaco de una nueva frustración que se incorpora en la frustración universal: al agregarse al universo el yo recién nacido, el cual en la obra de nuestro poeta no pasa de ser un cuerpo, cuyo conciencia es también conciencia de un cuerpo $\mathrm{y}$ de sus necesidades primarias, las alimenticias en primer lugar) priva a tados aquéllos que existían anteriormente de cuanto él mismo se apropia: "Todos mis huesos son ajenos; yo tal vez los robé". El ser que quería repartir su compasión entre los demás es el mismo que, por el solo hecho de existir, aumenta la miseria y la penuria ajenas. "Tal vez", "acaso"; la búsqueda de metáforas o vocablos selectos ha pasado de moda.

La palabra primitiva y apenas pronunciada cede en la estrofa final a una tentativa última de organización fundada siempre en la

(5) En la segunda parte de la estrofa encontramos sin embargo de nuevo una supervivencia de metáfora modernista cn los versos: "con las dos manos santas....". 
emoción obscurca y balbuciente : y es así como reaparecen, al teminar, la escena de la primera estrofa impregnatia de una nota nueva de tristeza y la ardorosa aspiración de la segunda estrofa, renovada y enriquecida por la conciencia más aguda de una vaga pero inmensa culpabilidad. (6).

En Agape (p. 54) han desaparecido totos los recuerdos propiamente literarios (con excepción tal vez de los versos: "No he visto, ni una flor del cementerio/ en tan alegre procesión de luces"); la humilclad absoluta del lenguaje corresponde exactamente a la absoluta humildad del poeta, semejante a aquélla que se manifestara en poemas Humanos. "Y yo no sé qué.... yo no sé qué...": la incredulidad para hablar y comprender es aquí más evidente que en ningún otro poema examinado hasta ahora. EI poema está estrechamente vinculado en su totalidad con el mismo sentimiento de culpa cuyo brote inicial acabamos de presenciar en El Pan Nuestro. El elemento temparal de siempre - "la tarde", elemento mortuorio- queda de nuevo evidenciado con una luz particular.

La existencia toda, experimentada como un robo, un latrocinio para con los demás, exige con una voz de una pureza casi física una reparación, aquella reparación precisamente que no le es dado realizar por la ausencia o indiferencic de los otros, las frustrados, las victimas ("no me han pedido en esta tarde nada". volvemos a encontrar, pero singularmente ampliado, el "yo no debo estar tan bien" de El Palco Estrecho). La 'muerte acdiario sufrida es el equivalente de esa imposible reparación; $\alpha$ cada día le corresponde su muerte : en esta tarde que poco he muerto; a cada día le corresponde su parte de muerte, de restitución, y el bienestar que hoy experimentamos lo hurtamos a ese capital de muerte que se despliega y extiende "en todas las tardes de esta vida". Los dos últimos versos del poema que sintetizan versos anteriores no son sino el sordo martilleo de un sentimiento cuya paráfrasis es más que cualquier otra inútil o inef́icaz. Todos aquellos rasgos que nos han parecido los más personales de Vallejo se encuentran pues reunidos en el presente poema.

Amado Alonso ha insistido en el carácter romántico de la poesíce de Neruda y no han faltado quienes expresaron un juicio similar

(6) Es evidente que no entendemos la palabra en un sentido filosifico preciso; dla cxpresa tan sólo el dolor confuso y primitivo de tener que colaborar a la miseria, y va por lo tanto dirigida hacia una inmensa compasión. 
respecto a las primeras producciomes de Vallejo. Pero cualquiera que sea el fondo común que podamos encontrar, lo fundamental y distintivo sigue siendo la relación que en cada poeta se establece entre la experiencia íntima y su traducción, el mado propio cie expresarla : la expresión de Vallejo en un poema como Agape se ha liberado del caudal estético de figuras $y$ ponsamientos esccgidos oue aceplura aún en poemas anteriores; la expresión nace entoncess unida al sentimiento de agonía y desnudez corporal del cual el posta no puede en ningún momento librarse, y aue afirma obstinadamente, algunas veces, ccmo en el caso presente, fuera de tada evocación de un cuadro exterior, y otras veces, como en El Pan Nuestro, dejanclo que surja de la presencia misma del universo familiar y limitado en donde ocurre la Existencia diaria.

En las Canciones de Hogar dicho universo representa asimismo el punto de partida: es un universo gravado desde el principio con una carga emctiva directa y precisa.

El pcema Los Pasos Lejanos (p. 74) está enteramente estructurado mediante la superposición de dos presentes espacialmente separeclos. El poeta no evoca el hogar que ha abandonado y en el cual unos seres amado piensint constantemente en gel, sino chue se lo "representa" en el sentido literal de la palabra os mejor dicho, transporta su propio presente al presente del padre y la madre. La distancia es negada y al mismo tiempo parcadójicamente afirmada con carácter aún más irremediable; pues el poetar en esa forma presencia su propia ausencia, instalado en los lugares mismos en los que todo revela que él está ausente; pero, como a pesar del esfuerzo no logra superponer su presente al presente lejano, helo cquí igualmente ausents en el presente.

En los primeros versos la afirmación inicial no parece encerrar dificultod alguna: "Mi padre duerme...": uno se imagina esa escena directamente descrita, pere ya el cuadro familar es interpretado en forma de unci oposición en el seno mismo del presente (la primera serie cle adjetivos de idéntico valor sentimental: "augusto, apacible, dulce" es compensada por el solo odjetivo "amargo" que viene después); la verdadera dualidad de semejante cposición va a precisarse en la segunda estrofa. Dentro del marco así indicado el poema se desarrolla luego en forma de visión, una visión humilde tan adherida a la realidad 
inmediata que parece que el poeta no escribiera sino que hablara $\alpha$ media voz, ayudándose con el ademán o la mirada ("mi madre pasea allá en los huertos") y estableciendo con el lector la complicidad que se requiere de un confidente.

El carácter en extremo sencillo de la intuición confiere a la atmósfera general del poema un tono de nostalgia definitiva porque es experimentada en relación con un presente insalvable, y sin otro atenuante que la ternura. Los medios expresivos son completamente perscnales; el tercer verso parece sin terminar y el adjetivo "duice" se prolonga con ilimitada resonancia (un procedimiento idéntico reaparece en la $2^{\text {f }}$ y $3^{\alpha}$ estrofa). Todo lo que es ausencia y separación es referido al poeta (Vallejo no dice: "si hay algo en él de amargo será pensar en mí que estoy ausente" sino que escribe : "si hay algo en él de amargo seré yo", y resulta que un sentimiento confuso de culpa se cculta también en el hecho de estar ausente), mientras que to lic elementos relacionados con la visión misma coinciden en formar una sola impresión de calma, dulzura y proximidad - la cual proximidad es asimismo una cualidad propia inseparable de la dulzura. "Está ahora tan cerca": la proximidad cobra en ésta última expresión un valor absoluto confirmado luego por el verso que sigue y se le opone: "si hay algo en él de lejos; lo "cerca" y lo "lejos" vienen a existir ahora fuera de toda determinación particular de distancia.

En Vallejo un modo inesperado $Y$ completamente nuevo de apropiarse las palabras "se sustituye entonces victoriosamente a la elaboración tradicional de las figuras o metáforas: "saboreando un sabor ya sin sabor" - la calidad emctiva se crea mediante utilización de un mismo vocablo hasta agotarlo, a no ser que el sentimiento irrumpa en una serie de vocablos de repente apartados de las relaciones ordinarias del lenguaje: "el hogar sin bulla/ sin noticias/ $\sin$ verde/ $\sin$ niñez...; palabras que pertenecen a zcnas distintas del lenguaje resultan en esa forma reunidas en una secuencia que traduce la invasión de un sentimienio determinado. $Y$ es así como en la estrofa siguiente leemos los versos aplicados a la madre: "Está ahora tan suave/ tan ala, tan salida, tan amor", - los tres sustantivos se convierten de golpe en adjetivos, los cuales en su progresión misma (de "ala" a "amor" se evidencia una espiritualización progresiva) objetivan el sentimiento con una claridad inesperada, susceptible tal vez de reducir la incapacidad expresiva del "Yo no sé".

Los cuaitra últimos versos de Pasos Lejanos (el último de todos es el múrs mecliocre) deccren un poso en cuanto a la atmósfera general 
se refiere, pero conservan interés ya que al ampliar el cuadro hasta cubrir la "tarcie" entera nos recuerdan la vinculación en la poeśa do Vallejo de la "tarde" con todas las carencias y privaciones de la vida.

En Enercida (p. 75) al contrario triunfa la "mañana". El punto de partida, como en el poema precedente, es una visión del hogar, pero sin que nada, ahora traduzca la distancia o la lejania. En la evocación se mezclan elementos presentes y otros traidos por la momoria (verbos al pretérito perfecto o imperfecto), sin orden aparente; pero ya en Ia segunda linea el poema encuentra su tiempo propio y la atmósfera correspondiente : "en la mañana pajarina" (el neologismo del adjetivo, que evoca toda la bulla alegre y clara del amanecer, tiene gran fuer$z a$ expresiva). Los dos últimos versos de la $2^{\circ}$ estrafa precisan esa sugerencia del comienzo y por más que la metáfora de la mañana como hermana de caridad tenga una estructura a lo Herrera y Reissig (cí. más abajo: "el beato campanario"), su valoración como imagen directora de todo el poema es completamente nueva. La sensación predominante del tiempo que hemos señatado en Vallejo enlaza y confunde lo humano con lo tempcral: los momentos del tiempo se individualizan : "la mañana le acompaña..." y los seres a su vez encuentran equivalencia en esos momentos : "mi padre es una víspera....".

En la primera parte de Enereida todos los detalles contribuyen a formar la oposición pajdrg-mañana] e el parhe ocupa el primer plano únicamente relacionacio con lo que es recuerdo y pasado (la secuencia de palabras : "Llevar, Grae, abstrádo.... resesulta particularmente característica al respecto), pero bruscamente es el medio matutino, en el que la vejez paterna se encuentra envuelta, el que triunfa. La segunda parte del poema se inicia con un grito de victoria ("Día eterno es éste...") que la profusión de adjetivos en el espacio de 2 versos pror longa de rnanera singular : el tiempo entero se salva y redime en aquel instante, al mismo tiempo virgen ("ingenuo, infante") y glorioso ("coral, oracional") (7).

Semejante canto de victoria es bastante raro en Los Heraldos Negros para que tratemos de caracterizarlo: no se somete a la menor elaboración intelectual y no está en contradicción con lo que hemos afirmado de la expresión propia de la poesía de Vallejo, tan pcro especulativa. La visión, el recuerdo, todos los elementos relacionados

(7) La retınión en dos grupos de dichos adjetivos prescuta por lo demis una evidente base musical: "ingenuo, infante, - coral, oracional". 
con la imagen del padre ceden tan sólo a una emoción más general en la cual los sentidos mismas participan (es el cuerpo el primero en hundirse en la atmósfera matutinal) y el himno triunfal surge al prorrumpir en palabras una emoción demasiado violenta para contenerse y al misrno tiempo para ser elaborada o posteriormente asumida. El poeta se contenta can afirmarla y repetir : "aún...., aún...., aún...." $y$, si bien la afirmación resulta en éste caso excepcionalmente feliz, no por eso se distingue fundamentalmente de aquéllas, clolorosas, que hemos encontrado en anteriores oportunidades. Su criginalidad consiste sólo en su virtud de redención, que anuncia o recuerda la aspiración patente en La Cena Miserable ("cuando nos veremos al borde de una mañana eterna....").

En la $3^{\circ}$ estrofa, el tiempo, desde el principio sensible en la decrepitud paterna, es recuperado por intercesión de la inocente "mañana" : cuanto había sido perdido es anunciado ahora como porvenir; el futuro, todo, repetirá todo el pasado. La última estrofa del poema se caracteriza entonces por un doble movimiento ascendente que descans $\alpha$ en una doble oración subordinada " cuando....cuando....", antes de terminar en una evocación dichosa y reconciliada : " $O$ h, padie mío!" - el padre cuya decadencia temporal había dominado la visión inicial se convierte aquí en la prueba suprema del triunfo sobre el tiempo.

Es notable además la selección de los elementos que integran esta última estrofa. Por un lado (primera parte de la estrofa), los elementos de la niñez; cotidianos, fomiliares lyt'thabrá empanadas; y yo tendré hambre..." : la sensación del hambre con el sabor de los alimentc:s, desplazando los recuerdos primitivos, se instala ahora en el futuro (un hombre por una vez tranquilo y hasta dulce : "el buen ciego mélico"). Por otro lado (segunda parte), los elementos del tiempo espiritualizado que repiten la "mañana pajarina" del principio - sensación de amor y paz cubriendo el infinito y la eternidad y llenando en cierta forma el deseo expresado en Absoluta, infancia salvada no tanto en los sueños que hacía, como en su cuerpo mismo y en las necesidades más humildes del cuerpo.

Este poema, paema de salvación (cuyas notaciones de detalle, cabe indicarlo, no siempre son del todo nuevas), señala por cierto una pausa en la angustia latente en todo el libro (la apoteosis matutina no puede realizarse sino volvienda el poeta al hogar de otrora donde el hambre $\mathrm{y}$ otras necesidades eran dulces porque podían ser satisfechas por los padres), pero pertenece de todas maneras por su estructura $y$ desarrollo a la manera más personal de Los Heraldos Negros. 
Sin embargo, el regreso al hogar puede volver a! contrcirio más definitiva la destrucción operacia por el tiempo : el poema $A$ mi hermano Miguel (p. 71) está escrite en memoria de Miguel, el penúltimo de loz hermanos de Vallejo, el mismo que por su edad había compartido los primeros juegos del poeta y habia muerto luego premaluramente. El precedente de Valdelomar escribiendo scbre un tema si no idéntico, por lo menos similer El hermano ciusente en la cena cie pascua, el precedente de Vallejo mismo cuya última ccmposición publicasa en Ciullua Infantil se titulaba $A$ mi hermano Miguel (8), nos sirven para subrayar más aún la originalialad del presente poena.

Ya en el primer verso, la interpelación directer al homano muerto anuncia la relación particular quei el autor cie Trilce y Poemas Humanos manifestará tener con los muertos, sintiendo caue exisien confusamente en una zona inasequible, radicalmente extraña a los vivos y no obstante vagamente comunicable. En medio de alguias expresiones más elaboradas el paeta vuelvo a encontrar el lenguajo do lu niñez para hablar (los frogmentos hablados son preponderantes) con aquel que ya no puede contestarle y de; la repetición de los movimientos ("ahora ya me escondo") y (rases de otrcra, en un presente en conde se manifiesta una carencia profunda ("nos haces una falta sin fondo"). la carencia de lo qué ha desaparecido y quisiera reproducirse a través de su persistencia afectiya on el requerdo, et de cesa repetición nace finalmente cierta confusión del pasado y el presonte.

En los dos úrtimos versos Vallejo ya no evoca la infancia, sino que. sin el menor disfraz literario, se expresa directamente como un niño (cf. Trilce 5I) hasta el punto que el hermano muerto (hoy) y el hermano que juega al escondite (otrora) se superponen, dejando establecer como una duda sobre la realidad de la muerte. La angustia y la ternura son ahora angustia y ternura de un niño : es al nivel de éstas experiencias elementales, que no pueden nunca traducirse por completo y menos aún definirse, donde se sitúa el acento más pexscnal del poeta, y es también a partir de ellas que se insinúan lás únicas formas posibles de superación.

(8) He reproducido el peema en : $M_{a} u$ del Sur, no 8 , art. cit. Los primeros versos del segundo terccto : "Advierto a nuestra madre......." son los úlnicos cu introdu* cir a la vez que una brusca familiaridad una tonalidad más personat. 


\section{CONCLUSION}

Jua expresión personal de un artista no se confunde generalmente con su expresión primitiva : la cultura del poeta (lo que ćl ha leído o aprendicio), influye al principio en la farma como escribe o trascribe su experiencia propia, y asimismo impone un lenguaje de acuerdo con un medio culiural determinado a aquello que el nuevo escritor encuentra en sí mismo de más personal y auténtico : la deuda de Vallejo a las más diversas manifestaciones del modernismo (simbolismo, precreacionismo de Herrera, impresionismo) resulta evidente desde una primera lectura de Los Heralcios Negros, pero al mismo tiempo hemos comprobado como, en gran parte de los poemas, el autor se libera de las influencias para comunicar sin ningún rodeo sus intuiciones más prcílunas. El libro es el testimonio de esa progresiva aparición de una verdad poética esencialmente inconfundible: inclusive en los poemas más influenciados por obras ajenas no íaltan, por lo común, uno que clio elemento que manifiestan una personalidad mal acordada con las formos tradicionales (ruptura del ritmo, exageración barroca en las imágenes, intervención familiar, combinación de inspiraciones diferentes en el interior de un mismo paema, etc.), mientras que los rasgos culturales y literarios muy pacas veces desaparecen del todo de las composiciones más personales.C Ca de Letras

Lo que integra immediatamientelic Vallejos en una corriente pośtica general que se inicia en los años de la primera guerra mundial es su abandono desde el primer libro y de una vaz por todas de la preocupación por la forma bella y el lenguaje pulcro. Ia poesía de Eguren, con sus encantos misteriosos, realiza en el lenguaje una selección de elementos regida por una preccupación de orden estético. El impresionismo y el intimismo han introducido el "prcsaismo" en poesía, pera tan sólo un prosaismo descriptivo, anecdótico; Vallejo nunca se ciñe al cuadro de la poesía impresionista o intimista; $y$, si bien se acer$\mathrm{ca}$ a ella por su atención a las cosas asequibles de la vida cotidiano. dicha atención en él corresponde a una exigencia imperiosa que abandona pronto la anécdota : es por contacto de las ccisas de uso diario cómo Vallejo experimenta, no en forma episódica sino definitiva la angustia del abandono y el dolor devorador del tiempo.

Desde entonces su poesía es una poesía balbuceada é inconclusa, incapaz de escaparse de la sensación de las amenazas oscuras o de los deseos elementales que el escritor afirma y repite sin lograr 
nunca indivicualizarlos, confesando su impotcncia frento a las fuerzas primitivas sin explotar (ol "yo no sé" aparece a través do to lo ol libro) Y por otra parte (confusamente consciente de una culpabilided primigenia, la cual no puede definir ni redimir (yo quisiera..." ) : unas fuerzas primitivas cuya experiencia es casi impersonal ("hay golpes... hay ganas..." ) y, al abarcar la conciencia de su cuerpo, el sontimiento irracional de la culpa ("yo no debo estar tan bien.... - quisiera.... suplicar $a$ no sé quién perdón....").

De ahí que la peesía de Los Heraldos Negros utilice cada vez menos el prestigio de las metáforas e imágenes. De ahí çue progrese fuera de las normas légicas ordinarias (hemos visto en Deshora un "pues", en Agape un "porque" privados de su valor sintćctico corriente, que introducían una conclusión puramente emotiva sin ningún equivalente lógico) y resulta por lo mismo más próxima a la lengua hablada que no a la lengua escrita en su vocabulario (palabras y giros locales: "recién llego... qué estará haciendo eslu liora mi.... Pita....") c. mús aún en su estructura (véase además del "pues" y el "porque" anteriormente citados, todos los "bueno", "pues", "pero", las interrupciones indicadas por los puntos supensivos, etc.) - más próxima también al lenguaje de los niños, que al de los adultos (cf, el final de $A$ mi hermano Miguel). De ahí finalmente que, en la mayo. ría de los poemas, encontremos tantas reapariciones de vocablos o fragmentos del discurso, Qunto con las repeticiones que traducen la persistencia del sentimienta impropiö Coobjetivarse completamente.

Entonces, quedando demostracla la insuficiencia del lenguaje, el poeta comienza a tomar las palabras en acepciones poco corrientes ("el restañante acliós, el día infante, etc.") y luego a crear nuevas palabras como lo hacía Herrera y Reissig ("bizantinar, istmarse, etc."), pero logranda a veces una resonancia expresiva inesperada ("mañana pajarina"). También reúne los vocablos ya existentes en series gramaticalmente revolucionarias ("tan suave, tan ala, tan salicla, tan amor"), - agota un vocablo determinado dóndole vueltas y más vueltas ("una vida de vida agonizante..... saboreanda un sabor ya sin sabor...."). Descubrimos en los ejemplos que preceden los elementos de uma utilización propia del lenguaje que se realizará con mayor libertad en la época de Trilce (la confesión primitiva de impotencia del "yo no sé" concluye paradójicamente en una especie de refundición, tal vez liberadora, del lenguaje).

Hemos puesto varias veces de manifiesto la relación existente entre una experiencia que siempre aborta al tratar de expresarse, con 
una sensación particular del tiempo, en la cual la evocación a distancia, tanto espacial (Los pasos lejanos) como propiamente temporal ( $A \mathrm{mi}$ hermano Miguel), tiende a resolverse por la supresión de toda lejanía y la superposición de dos realidades distintas en el presente actualmente vivido, donde la ausencia, lo misma que el pasádo, son experimentados como defecto o privación. La reaparición casi obsesiva de la "lluvia" y la "tarde", como tiempo de la muerte, resulta estrechamente vinculada con la sensación de todo lo que hace falta y simultáneamente de tado lo que amenaza; la vida misma es sentida en función de la tarde : "en todas las tardes de esta vida" (Agape), "pues de la vida en la perenne tarde" (Deshora).

El poeta, incapaz de desprenderse de su experiencia inmediata, para asumirla en forma abstracta, no puede, en el exceso de su abandono, sino formar un deseo, una aspiración contra los límites inexplicados que lo encierran (Absoluta), y es en el centro mismo de la sensación presente eternizada donde surge, como ya dijimos, el grito triunfal de Enereida, gracias al cual el tiempo todo es recuperado por la proyección del pasado hacia un futura para siempre liberado (la mañana eterna, el "día eterno" responden a la "perenne tarde" de Deshora). $\mathrm{De}$ todas maneras ese momento de gloria y liberación, anunciado en La Cena Miserable y casi realizado en Enereida, es excepcional y no logra hacernos olvidar la expresión de angustia que traduce de ordinario el sentimiento irremediable del tiempo iven la renovación del lenguaje iniciada por Vallejo, los vocablos del lenguaje temporal adquieren desde el principio un papel primordial; el punto de partida de semejante procedimiento (espiritualización de los elementos temporales) lo podemos encontrar en Herrera y Reissig o en cierto afón "preciosista" ("un nido azul de alcndras que mueren al nacer"), pero en poemas como Espergesia ("y que no me vaya/ sin llevar diciembres/ sin dejar eneros"). como Fresco ("hay un cariño que no nace nunca/ que nunca muere") y sobre todo Agape ("y hoy he muerto qué paco en ésta tarde!") o Deshora ("pues de la vida en la perenne tarde/ nació muy poco/ pero mucho muere!"), tan sólo subsiste la necesidad de transmitir la experiencia agónica y lógicamente pradójica de una vida con más carga de muerte que de vida - experiencia que será mucho más tarde profundizada en Poemas Humanos.

La unidad del primer libro de Vallejo consiste en la tonalidad afectiva especial ya indicada en el poema inicial : una zozobra sin re- 
curso alguno, la zozobra de un niño desamparado (sienclo el hambre la manifestación menos transitoria de ese desamparo), de un niño alejado del hogar primitivo $y$ que se siente antes de tiempo huérfano $y$ abandonado (los poemas de Trilce serán escritos después de muerta la madre, pero el papel entonces desempeñado par ésta última está anunciado en Los Heraldos Negros : el "Madre nuestra" de Las Piedras substituido al "Padre nuestro" evangélico). Esa misma congoja no logra justificarse y quizás al mismo tiempo redimirse sino por una ternura apasionada que envuelve hasta las piedras (Las Piedras). El lenguaje americano y especialmente andino, con su abundancia de diminutivos que Vallejo utiliza en más de una oprtunidad ("los dos nos dormiremos como dos hermanitos, - las manitas sumisas de tus tardes, - aún la veo envueltita, - aún reirás de tus pequeñuelos"), resulta en ese punto perfectamente adaptado a la exigencia íntima del poeta, que a diario madruga "al crudísimo día de ser hombre".

Los poemas de Nostalgias Imperiales no representan sino una etapa rudimentaria hacia la expresión original; la liberación de la herencia cultural, probablemente menos difícil para el americano andino de lo que sería para un europeo, se verifica sobre todo cuando el poeta vuelve a encontrar el lenguaje muy poco conceptual de las sensaciones y sentimientos primigenios. Los Heraldos Negros escapan de la retórica a lo Chocano, lel peligro mayor paralla poesía americana, por permanecer fieles a ung oscura inquietud apenas elaborada y que no intenta adcrnarse con galas postizas o ajenas. Puede ocurrir entances que el lenguaje del niño se confunda con el del hombre de las alturas andinas en constante relación con las fuerzas cósmicas que Vallejo evocará en Fable Salvaje, - pero lo que el paeta debe a uil ambiante terrestre privilegiado, cualquier persona que se adentre en su propia niñez puede encontrarlo nuevamente en aquellas zonas efectivas de la angustia y la ternura que preexisten en cada uno de nosotros a todo proceso o tentativa de elaboración intelectual. Y es así como, desde el primer libro, la poesía de Vallejo cobra valor universal. 